Evaluation of Historical Beryllium Abundance in Soils, Airborne Particulates and Facilities at Lawrence Livermore National Laboratory

M. Sutton, R. K. Bibby, G. R. Eppich, S. Lee, R. E. Lindvall, K. Wilson, B. K. Esser

May 1, 2012

Science of the Total Environment 
This document was prepared as an account of work sponsored by an agency of the United States government. Neither the United States government nor Lawrence Livermore National Security, LLC, nor any of their employees makes any warranty, expressed or implied, or assumes any legal liability or responsibility for the accuracy, completeness, or usefulness of any information, apparatus, product, or process disclosed, or represents that its use would not infringe privately owned rights. Reference herein to any specific commercial product, process, or service by trade name, trademark, manufacturer, or otherwise does not necessarily constitute or imply its endorsement, recommendation, or favoring by the United States government or Lawrence Livermore National Security, LLC. The views and opinions of authors expressed herein do not necessarily state or reflect those of the United States government or Lawrence Livermore National Security, LLC, and shall not be used for advertising or product endorsement purposes. 


\title{
Evaluation of Historical Beryllium Abundance in Soils, Airborne Particulates and Facilities at Lawrence Livermore National Laboratory
}

\author{
Mark Sutton ${ }^{*}$, Richard K. Bibby, Gary R. Eppich, Steven Lee, Rachel E. Lindvall, Kent \\ Wilson and Bradley K. Esser
}

Lawrence Livermore National Laboratory, P.O. Box 808, Livermore, CA 94551

\begin{abstract}
Beryllium has been historically machined, handled and stored in facilities at Lawrence Livermore National Laboratory (LLNL) since the 1950s. Additionally, outdoor testing of beryllium-containing components has been performed at LLNL's Site 300 facility. Beryllium levels in local soils and atmospheric particulates have been measured over three decades and are comparable to those found elsewhere in the natural environment. While localized areas of beryllium contamination have been identified, laboratory operations do not appear to have increased the concentration of beryllium in local air or water. Variation in airborne beryllium correlates to local weather patterns, PM10 levels, normal sources (such as resuspension of soil and emissions from coal power stations) and not to LLNL activities. Regional and national atmospheric beryllium levels have decreased since the implementation of the EPA's 1990 Clean-Air-Act. Multi-element analysis of local soil and air samples allowed for the determination of comparative ratios for beryllium with over 50 other metals to distinguish between natural beryllium and process-induced contamination. Ten comparative elemental markers (Al, Cs, Eu, Gd, La, $\mathrm{Nd}, \mathrm{Pr}, \mathrm{Sm}$, Th and Tl) were selected to ensure background variations in other metals did not collectively interfere with the determination of beryllium sources in work-place samples at LLNL. Multi-element analysis and comparative evaluation is recommended for all workplace and environmental samples suspected of beryllium contamination. The multi-element analyses of soils and surface dusts were helpful in differentiating between beryllium of environmental origin and beryllium from laboratory operations. Some surfaces can act as "sinks" for particulate matter, including carpet, which retains entrained insoluble material even after liquid based cleaning. At LLNL, most facility carpets had beryllium concentrations at or below the upper tolerance limit determined by sampling facilities with no history of beryllium work. Some facility carpets had beryllium concentrations above the upper tolerance limits but can be attributed to tracking of local soils, while other facilities showed process-induced contamination from adjacent operations. In selected cases, distinctions were made as to the source of beryllium in carpets. Guidance on the determination of facility beryllium sources is given.
\end{abstract}

\section{Keywords}

Beryllium, soil, airborne, particulate, carpet, dust

\footnotetext{
* Corresponding author. Present address: Chemical Sciences Division, L-223, Lawrence Livermore National Laboratory, P.O Box 808, CA 94551, USA. Tel: +1 (925) 424-2137; Fax: +1 (925) 423-0153; E-mail address: sutton18@llnl.gov
} 


\section{Introduction}

Beryllium $(\mathrm{Be})$ is a naturally occurring element used in many industries in a variety of forms - most commonly metals, oxides, and alloys for the manufacture of materials ranging from nuclear components and electronics to golf clubs and aircraft brakes. Beryllium has been machined, handled and stored in several buildings at LLNL for 60 years. Beryllium contamination (air, soil, water etc) has been identified at 73 US Department of Defense (DOD) facilities (USGAO, 2001), and over 300 Department of Energy (DOE) related sites including contractors (USDOE, 2010; USGAO, 2001), with OSHA identifying hundreds of beryllium-use sites across the US (USGAO, 2001).

In 1999, the United States Department of Energy acknowledged the hazards associated with the machining of beryllium and the necessary protection of workers by releasing 10 CFR Part 850 "Chronic Beryllium Disease Prevention Program; Final Rule" (USDOE, 1999). The rule implements the required measurement and control of exposure to airborne beryllium in the workplace, setting a limit of surface contamination for releasable items to $0.2 \mu \mathrm{g} / 100 \mathrm{~cm}^{2}$, an action level of $0.2 \mu \mathrm{g} / \mathrm{m}^{3}$ for a worker's breathing zone and defers to 29 CFR 1910.1000 "Occupational Safety and Health Standards" (OSHA 1999) for an occupational exposure limit of $2.0 \mu \mathrm{g} / \mathrm{m}^{3}$. In fact, 10 CFR Part 850 allows for a more stringent airborne exposure limit to be implemented beyond those in 29 CFR 1910.1000 if found necessary. Furthermore, 10 CRF 850 sets release rates for bulk samples at " the concentration level of beryllium in local soil at the point of release". Because bulk samples are commonly (and usefully) taken when assessing soil or facility contamination, the lack of specific guidance and criteria for assessment of beryllium in bulk samples often presents a problem, especially where natural beryllium levels in soils are high, or where Be is present as an impurity rather than a commodity. For example, Taiwo et al. (2010) recently found a prevalence of beryllium sensitization among aluminum smelter workers who had no direct contact with beryllium processing. Comparing the concentration of beryllium with other metals in environmental and workplace samples may provide useful insight into the nature and behavior of beryllium in that environment, specifically determining whether beryllium is present from natural sources such as soil, or process-induced.

The geochemical behavior of Be in soils is poorly understood (Taylor et al., 2003), but most studies agree that the chemistry of Be in the environment is similar to that of aluminum (Bohn, 1972; Romney and Childress, 1965; Sutton and Burastero, 2003); for a contrary view, see Anderson et al (1990). Analysis of dissolved and acid available particulate beryllium in UK surface waters showed linear correlation with aluminum, cobalt, chromium, iron, manganese, nickel, yttrium and the lanthanides (Neal, 2003). USGS data on soils (Smith et al., 2005) allowed comparison of the elemental composition in the top $5 \mathrm{~cm}$ of soil across the US, which is the preferred sample medium of the public health community. Not surprisingly, the USGS data showed a correlation between $\mathrm{Be}$ and $\mathrm{Al}$, with a national ratio of $2.81 \times 10^{-5}(\mathrm{n}=275, \mathrm{r}=0.77)$. Beryllium minerals typically contain Si and Al (Hormann, 1969), and conversely, aluminum minerals contain beryllium. Additionally, the highest beryllium correlations were also observed using USGS soil data for cesium, gallium, lanthanum, potassium, rubidium, 
thorium and yttrium (Smith et al., 2005). All other metals in the USGS study had a correlation coefficient below 0.75 when compared on a national level. The data suggest that some metals (including Al, Cs, Ga, La, K, Rb, Th and Y) may behave similarly to Be in soils or deposits, but also that correlations may vary for certain specific sites. Given that the composition of airborne particulates is typically driven by soil resuspension and industrial processes, it is reasonable to assume that soil, air and surfaces that are contaminated with man-made beryllium would have elevated beryllium concentrations in relation to these analogous elements. Ogurek (2004) and Gran and Word (2011) have recently identified beryllium contamination at Nevada offices associated with the Nevada Test Site using Be/Y ratios, despite Nevada having some of the highest background Be content in soil (Smith et al., 2005).

Unfortunately, some of these comparative metals are generated from industrial processes that may interfere with the measurement of beryllium to metal ratio. For example, aluminum is used in many industrial applications, cesium in the oil industry, gallium in semiconductors, lanthanum in hybrid automobile batteries, potassium in fertilizers, rubidium in telecommunication testing standards, thorium in aircraft engines, yttrium in television phosphors, and a variety of elements in recycling plants. Moreover, there is local and regional variation in natural soil and particulate matter composition. Therefore, comparison with as many metals as possible should be used in determining whether anthropogenic beryllium contamination is present, and the ratios in local soils with correlation coefficients higher than those derived from the USGS or other national body should be preferred. In addition, since air particle concentrations and soil composition can be affected by local emissions, and given then varying nature of soil in other regions and countries, it is also recommended that samples from nearby locations be taken to assess specifically which elemental markers best represent natural analogues for each beryllium-handling facility or environment. For the LLNL study, those metals were Al, $\mathrm{Cs}, \mathrm{Eu}, \mathrm{Gd}, \mathrm{La}, \mathrm{Nd}$, Pr, Sm, Th and Tl. Analytical techniques such as inductively coupled plasma mass-spectrometry (ICP-MS) provide multi-element data, typically in a oncethrough analysis, providing a large number of elemental ratios to compare with beryllium (or other metal of interest) in a minimum amount of time.

Recently, beryllium was detected in LLNL facility carpets, including in some buildings that did not historically house beryllium activities (Sutton and Lee, 2009). LLNL soils and airborne particulates have routinely been collected and analyzed for hazardous and radioactive contamination for more than 30 years. This study compares the historical data with multi-element analysis of archived samples and recently collected facility carpet dust. Subsequently, historical beryllium abundance in LLNL soils and airborne particulates was assessed and compared to facility dust samples utilizing ratios with other correlated elements allowing a determination of natural versus process-induced beryllium in the workplace. 


\section{Data, Materials and Methods}

\subsection{Historical soil samples and data}

Historical data evaluated in this article include soil samples that were collected as part of two studies. The first study is an ongoing effort to monitor hazardous chemicals at LLNL, maintained internally by the Environmental Functional Area, where soil samples have been taken at various locations across both the LLNL main site (S200) in Livermore, CA and the LLNL Experimental Test Facility (S300) located between Livermore and Tracy, CA. Routine annual beryllium monitoring in S200 soil began in 1988 and ceased in 1994. Soil samples continue to be taken at S200, but they are not specifically analyzed for Be. Beryllium monitoring at S300 soil began in 1991 and continues to be monitored annually. Typically, soil samples are taken from the top $5 \mathrm{~cm}$ of soil at specific locations. From 1974 to 1988, LLNL's Hazards Control team performed sample digestions and analyses. Between 1989 and 2001, samples were analyzed by an off-site independent laboratory, and from 2002 onwards digested and analyzed by LLNL's on-site Environmental Monitoring Radioanalytical Laboratory (EMRL).

A separate in-house soil study was performed by LLNL in 2007 in which soil samples were collected from 60 locations at S200 to a depth of $1 \mathrm{~cm}$ (Mullins and Kamerzell, 2007). Samples underwent microwave digestion in nitric acid at $100^{\circ} \mathrm{C}$ for 25 minutes and were then analyzed by inductively coupled plasma - atomic emission spectrometry (ICP-AES). Selected multi-element analysis (including $\mathrm{Al}, \mathrm{Ba}, \mathrm{Cu}, \mathrm{Fe}, \mathrm{Mn}, \mathrm{Ni}, \mathrm{V}$ and $\mathrm{Zn}$ ) of each sample in 2007 provided evidence that beryllium to aluminum ratios could be used to distinguish between naturally occurring beryllium (e.g. soil and atmospheric dust) and localized anthropogenic contamination (e.g. from machining, handling, testing and tracking). The report noted that several points were removed from the analysis because of their proximity to potentially contaminated sites, but did not specifically identify those locations. We identify two outliers (discussion below), likely due to isolated berylliumcontaminated soil.

\subsection{Historical air filter samples and data}

LLNL's Environmental Functional Area performs monthly evaluations of airborne beryllium and other hazardous chemicals at 6 sampling locations within the S200 boundary and up to 11 different sampling locations in and around S300, including a control station placed near a traffic intersection in Tracy, CA. Filters are changed monthly, digested and analyzed for beryllium and other hazardous materials. As of the end of 2010, 2913 samples have been collected at S200, and 2375 samples collected from S300. As with soil data, the trend in results is published yearly as part of the LLNL Environmental Reports, the most recent of which is for calendar year 2010 (Jones et al., 2011), however no published analysis of historical data has previously been reported. 


\subsection{Facility carpet samples}

Bulk environmental sampling at LLNL was conducted to investigate the presence and relative level of beryllium entrained in carpets in work areas associated with buildings identified on the suspect beryllium facilities list. This was part of a larger effort to characterize surfaces in LLNL facilities by evaluation of bulk analysis data resulting from the collection of samples of dust from soil and work areas.

The collection of carpet dust samples is detailed elsewhere (Sutton and Lee, 2009). Specifically, this procedure was based on a combination of ASTM Method D5438-05 "Standard Practice for Collection of Floor Dust for Chemical Analysis", LLNL's industrial hygiene experience and instructions provided by the manufacturer. Bulk samples were obtained via a vacuum surface sampling collection method to collect particulate matter from the carpet or bare floor via vacuum-induced suction and separated mechanically by a cyclone. A high volume small surface vacuum sampler (HVS-3, Envirometrics, Inc. Venice FL) was used to effectively remove, separate and collect particles $\sim 5 \mu \mathrm{m}$ diameter and larger. A subset of these samples that included both facilities with known contamination and facilities that have never housed beryllium work were chosen for further analysis in this article.

\subsection{Recent multi-element analysis of selected historical soil, air and facility samples}

Archived soil samples were digested following the total silicate digestion method EPA 3052, with some modifications. Samples were aliquoted, weighed, and added to clean microwave vessels. A 3:1 mixture of concentrated $\mathrm{HNO}_{3}$ to concentrated $\mathrm{HF}$ was added to each vessel. Samples were digested in a two-step process at $170-180{ }^{\circ} \mathrm{C}$ for a total of 15 minutes. Samples were removed from the microwave vessels, transferred to clean Teflon vials, and dried down. Samples were dissolved in concentrated $\mathrm{HClO}_{4}$ to remove residual fluorides. Samples were dried down at $210{ }^{\circ} \mathrm{C}$ to drive off $\mathrm{HClO}_{4}$, and dissolved in $3 \mathrm{M} \mathrm{HCl}$ to produce stock solutions. This digestion method was chosen because it offers complete digestion of the sample rather than a hard leach. For analysis, splits of the stock solutions were aliquoted, dried down, dissolved in $\mathrm{HNO}_{3}$, and diluted to produce solutions with trace element concentrations within the dynamic range of quadrupole ICPMS instrumentation.

Digested soil samples were analyzed for trace element concentrations using a Thermo XSeries Quadrupole ICP-MS. Reproducibility and accuracy of trace element concentrations were assessed by measurements of soil standards NIST SRM 2709 and 2587. Concentration measurements of these standards were within the uncertainty of their certified values for most elements, including Al. Although no soil standards currently exist with certified Be concentrations, NIST SRM 2587 has an "information" Be concentration of $9.2 \mathrm{mg} / \mathrm{kg}$ (measured for the Certificate of Analysis by ICP-AES). We used this standard to assess elemental recovery of Be in the soil samples. Our measurement of Be in SRM 2587 was high by about $50 \%$; this result may be due to uncertainty in the "information" Be concentration. A recent beryllium oxide powder 
standard (NIST SRM 1877) may be used in future analyses to determine recovery of beryllium oxide, particularly in matrix-matched samples (Winchester et al., 2009 and Oatts et al., 2012). The high-fired beryllium oxide standard is more representative of the process-induced contamination that is likely to be found in beryllium handling and machining facilities. However, the use of beryllium oxide powder may necessitate additional beryllium controls in an analytical or industrial hygiene laboratory. Furthermore, future determination of beryllium may compare currently used $\mathrm{HNO}_{3} / \mathrm{HF}$ digestion with $\mathrm{NH}_{4} \mathrm{HF}_{2}$ extraction as detailed in ASTM D7458-08 "Standard Test Method for Determination of Beryllium in Soil, Rock, Sediment, and Fly Ash Using Ammonium Bifluoride Extraction and Fluorescence Detection”.

\section{Results and Discussion}

\subsection{Beryllium in local soil}

Beryllium concentrations in soil taken from a wide range of sampling locations in 2007 (Mullins and Kamerzell, 2007) at S200 fall between 0.10 and $0.65 \mathrm{mg} / \mathrm{kg}$. However, the authors noted several outliers but did not specifically identify their location or value. The authors performed multi-element analysis on the samples collected to determine the nature of the beryllium in each sample and found good correlation between $\mathrm{Be}, \mathrm{Al}, \mathrm{Ni}$ and $\mathrm{V}$, with derived tolerance limits for each normalized Be ratio that encompassed $95 \%$ of the normal population with 95\% confidence. Using Mullin and Kamerzell's upper tolerance limit (UTL $95 \% 95 \%$ ) for Be:Al of $5.07 \times 10^{-5}$, we identified two outliers (Figure 1) in the southeast and southwest corners of a facility in an area that was historically used

for beryllium activities including machining, waste handling, and storage (Dreicer, 1985). Excluding these two contaminated soil outliers from the population of background soils, the UTL $95 \% 95 \%$ for ratio of Be:Al is recalculated as $4.73 \times 10^{-5}$ with a correlation coefficient $(\mathrm{R})$ of 0.70 . The soil concentrations measured by Mullins and Kamerzell (2007) were similar to those historically measured at LLNL from 1988 onward as part of the annual environmental surveillance monitoring.

Statistical analyses of both historical (1988-1994) soil and Mullins and Kamerzell's (2007) data for S200, and the historical data for S300 (1991-2010) are shown together in Figure 2 and tabulated in Table 1. The results show that there is a difference in beryllium concentration in soils analyzed at S200 and S300, possibly due to beryllium-related activities at S300, but more likely due to the difference in soil type in the two locations. Livermore (S200) soils are typically loamy-skeletal, mixed, superactive, thermic pachic haploxeroll and whereas Altamont (S300) soils are fine, smectitic, thermic aridic haploxerert (USDA, 2008). Without analysis of natural soil levels at S300 before beryllium activities began, it is difficult to quantitatively assess the difference between S200 and S300 background levels, but it is fair to assume that the smectite-clay nature of the S300 soils would result in higher aluminum (and therefore higher beryllium) levels. At S300, beryllium concentrations in soil appear to have decreased from the early $2000 \mathrm{~s}$ compared to their peak values in the mid 1990s. While there have been environmental remediation efforts at $\mathrm{S} 300$, these have been largely focused on volatile organic carbon 
compounds, PCBs and depleted uranium, and have not specifically targeted beryllium cleanup.

Taylor et al. (2003) provides a good review of levels of beryllium in various environmental media and systems. Most notably, Be concentrations in soil range from 0.1 $\mathrm{mg} / \mathrm{kg}$ to $40 \mathrm{mg} / \mathrm{kg}$ (Anderson et al., 1990). Beryllium in soil at Moffett Field, CA (approximately 50 miles from LLNL) has Be concentrations ranging from 1.099 to 1.479 $\mathrm{mg} / \mathrm{kg}$ (Shireman et al., 1995). Beryllium content of common rocks spans 1 to $10 \mathrm{mg} / \mathrm{kg}$ (Fishbein, 1981) and world soil concentrations range from 0.1 to $40 \mathrm{mg} / \mathrm{kg}$ with an average of $6 \mathrm{mg} / \mathrm{kg}$ (Bowen, 1966; Drury et al., 1978). Beryllium concentrations in soil at Los Alamos, NM lie between 1.0 and $4.4 \mathrm{mg} / \mathrm{kg}$, and sediments range from $<0.1$ to 49.2 $\mathrm{mg} / \mathrm{kg}$ (LANL, 2001). In Nevada, soils at the Nevada Test Site (NTS) contained between $0.46 \mathrm{mg} / \mathrm{kg}$ and $4.65 \mathrm{mg} / \mathrm{kg}$ beryllium (Patton, 1992), and at the Yucca Mountain Program facility soils ranged from 0.116 to $1.5 \mathrm{mg} / \mathrm{kg}$ (Ogurek, 2004). Further analysis of the USGS data shows that the mean beryllium concentration in California soils is 1.1 $\mathrm{mg} / \mathrm{kg}$, while Nevada has a mean concentration of $2.4 \mathrm{mg} / \mathrm{kg}$. It is clear that Be concentrations in soil vary widely between sites, states, countries and geologies.

A study of three areas within the southeastern US found beryllium concentrations in soil ranging from 0 to $17.8 \mathrm{mg} / \mathrm{kg}$, although the mean Be concentration in each of the three areas studied was less than $0.15 \mathrm{mg} / \mathrm{kg}$ (Aelion et al., 2009). An earlier study by the same author (Aelion et al., 2008) in South Carolina found Be concentrations in soil to range up to $1.3 \mathrm{mg} / \mathrm{kg}$ with a mean of $0.41 \mathrm{mg} / \mathrm{kg}$. Previous studies by Shacklette and Boerngen (1984) report Be concentrations in soil ranging from $<1$ to $15 \mathrm{mg} / \mathrm{kg}$, while studies by Canova (1999) report a mean of $0.6 \mathrm{mg} / \mathrm{kg}$.

Soils on or near beryllium processing sites (for example at beryllium processing plant in India) have Be concentrations between 1.42 to $2.75 \mathrm{mg} / \mathrm{kg}$ (Thorat et al., 2001). In more contaminated sites, Be has been reported at the Franklin Slag Pile copper smelting plant to be as high as $129 \mathrm{mg} / \mathrm{kg}$ in the slag pile and $113 \mathrm{mg} / \mathrm{kg}$ in the surrounding soil (USEPA, 2001).

As noted earlier, USGS data on soils (Smith et al 2005) suggests good correlation between Be and other metals such as Al, Cs, Ga, K, La, Rb, Th and Y; and the Mullins and Kamerzell data (2007) for LLNL soil showed that Be correlated best with Al. More recent and thorough multi-element data has been collected on archived LLNL S200 soils from 2009. The results of correlation and UTL $95 \% 95 \%$ for these three studies are shown in Table 2. Figure 3 provides an example of the Be:Al data for S200 compared to the USGS data. Here it can be seen that LLNL soils are typical of those found in the US based on the Be:Al ratio. The UTL ${ }_{95 \% 95 \%} \mathrm{Be}$ :Al ratio for LLNL soil collected in 2009 (this study) is calculated as $2.04 \times 10^{-5}$, compared to the recalculated value from Mullins and Kamerzell of $4.73 \times 10^{-5}$ and the national value of $5.90 \times 10^{-5}$ calculated here from USGS data (Smith et al., 2005). This suggests that LLNL S200 soil is typical of other national US soils. The results also provide information that can be used to determine the natural levels of beryllium with respect to other metals below which surfaces and samples can be considered free from anthropogenic beryllium contamination per USDOE 10 CFR Pt 850 
(USDOE, 1999), further discussed in section 3.3.

\subsection{Beryllium in local airborne particulate matter}

While there is evidence that dermal exposure to beryllium causes beryllium sensitization (Tinkle et al., 2003), the most significant hazard associated with beryllium is from inhalation of insoluble particles that can lead to incurable lung scaring known as Chronic Beryllium Disease (which occurs in approximately a few percent of those exposed). Monthly historical airborne particulate data collected at LLNL S200 from 1974 to 2010 and at S300 from 1981 to 2010 were examined, with the results shown in Table 3 and Figure 4 . There is close agreement between the airborne beryllium concentrations in the two locations, which is not surprising given their relatively close proximity (15 miles), geographic location (inland) and similar weather patterns. The results are also plotted over time in Figure 5. LLNL is required to comply with Bay Area Air Quality Management District Reg 11 Rule 3 (BAAQMD, 1982), which prohibits releases exceeding $10,000 \mathrm{pg} / \mathrm{m}^{3}$ averaged over 30 days at any one sample location. It is clear from Figure 5 that this requirement has never been exceeded since records began in 1974 . Additionally, $99.96 \%$ of monthly air samples fell below the mean US atmospheric beryllium concentration of $\sim 500 \mathrm{pg} / \mathrm{m}^{3}$ reported by Fishbein (1981). It also appears from the data in Figure 5 that the airborne concentration of beryllium has fallen over time, with an average of $\sim 25 \mathrm{pg} / \mathrm{m}^{3}$ overall from 1974 to 2010 but only $5 \mathrm{pg} / \mathrm{m}^{3}$ in 2010 .

To further investigate the change in beryllium-containing particulate matter, national annual PM10 data from 1990 to 2010 (USEPA, 2012) is plotted in Figure 6 together with the average annual LLNL S200 beryllium airborne particulate concentration. The PM-10 standard includes particle matter with an aerodynamic diameter of $10 \mu \mathrm{m}$ or less and is a metric used by the EPA and other regulatory organizations to monitor air quality. This figure shows that there has been a significant reduction in beryllium particulate matter concentrations over LLNL corresponding to reduction in national PM10 levels since the implementation of the EPA's 1990 Clean Air Act which (among other criteria) required most power station scrubbers to be activated and forced many power stations to switch to coal with a lower $\mathrm{SO}_{2}$ content (such as powder river basin coal) (USEPA, 1990). The rule, which was primarily aimed at improving air quality and reducing acid rain, identified beryllium as one of the 189 hazardous chemicals requiring regulation and reduction. The decrease in airborne beryllium measured by LLNL corresponds to the national decrease in PM10 since the Clean Air Act. We conclude that LLNL's Be activities have not impacted local air quality.

Beryllium in the atmosphere results from both natural and anthropogenic sources. According to the CDC (ATSDR-CDC, 2002), 9.5 metric tons of beryllium and beryllium compounds are released annually to the atmosphere, of which $54 \%$ is from natural sources (windblown dust and volcanic particles), with $81 \%$ of the anthropogenic beryllium coming from electric utilities. Fishbein (1981) provided useful information on the sources, transport and alterations of beryllium in the environment, and projected 260 tons of Be annual air emissions from stationary sources in 1983, the vast majority of 
which originate from coal combustion. The magnitude of global coal-derived beryllium is not well known, ranging from 0.1 to $1,000 \mathrm{mg} / \mathrm{kg} \mathrm{Be}$, and oil typically contains 0.08 mg/kg (Bowen, 1966; Gluskoter et al., 1977; Heindl, 1970; Ruch et al., 1974). The elemental composition of coal burned at two western US power stations is given by Ondov et al.(1979), showed that the ratio of Be/Al for the selected coal was between 4.07 and $5.28 \times 10^{-5}$, not dissimilar to the ratio for soil in the US $\left(5.90 \times 10^{-5}\right.$, Smith et al., 2005). However, it appears that much of the beryllium in the fuel is associated with organic material and emitted as particulates (Tepper and VanOrdstrand, 1972) rather than the alumino-silicate fractions.

Before the implementation of the EPA's Clean Air Act, atmospheric beryllium concentrations of between 1.58 and $1.87 \mathrm{mg} / \mathrm{kg}$ may have originated from slag and ash produced by thermal power stations (Kubiznakova, 1987). Beryllium in the atmosphere is suspected to fall to earth as dry deposition or entrained in precipitation (Drury et al., 1978) and the highly insoluble nature of many Be-containing minerals (and $\mathrm{BeO}$ ) limits the amount of Be particles that dissolve in precipitation or in bodies of water.

Analysis of the monthly LLNL airborne particulate data also reveals seasonal variations in beryllium concentrations. The monthly data for S200 are shown in Figure 7 together with average monthly temperature, wind speed and rainfall at S200 between 2006 and 2010. The results clearly show seasonal periodicity with highs in late summer / early fall corresponding to elevated temperatures and wind speed, and lower precipitation. Lows in beryllium particulate matter occurs in the winter months relating to lower temperatures and wind speed, combined with and greater precipitation. The variation in a given year is typically an order of magnitude between summer and winter. The periodicity has existed each year since records began in 1974 and also occurs at S300 and the Tracy control station.

Beryllium-7 (Be-7) is a cosmogenic radionuclide (half-life $\sim 53$ days) produced by the continuous bombardment of earth's atmosphere by cosmic radiation. Be-7 attaches predominantly to aerosols in the submicron size range, and is susceptible to the same transport and depositional processes governing these aerosols, making it a useful tracer of atmospheric particulate matter (Doering and Akber, 2008). Several studies have shown that atmospheric Be-7 concentrations are seasonally variable, with a maximum in the summer season and a minimum in the fall/winter months (Azahra et al., 2004; Doering and Akber, 2008; Yamamoto et al., 2006). Feely et al. (1989) investigated the atmospheric Be-7 concentration at a large number of sites across the world. Two of the locations reported by Feely et al. (1989) are Richmond, CA from 1973 to 1977 and Tracy, CA from 1977-1981. Feely et al. (1989) note that while these two locations are geographically close (i.e. in the San Francisco Bay Area, 50 miles apart), their weather behavior is very different, with Richmond on the coast and subject to coastal fog, and with Tracy inland and subject to higher temperatures. To compare the trend in LLNL data, we overlaid S200 airborne total beryllium mass data from 1973-1980 (green solid line, right axis) with Feely's Be-7 activity data (red and blue broken lines, left axis) in Figure 8. There is close agreement between S200 data and that reported by Feely for Tracy, CA. In late fall and winter, rain occurs in both coastal and inland areas, so particulate matter 
concentrations are similar due to rain-out. In the spring, summer and early fall, coastal areas are cooler with onshore flow fog, while inland areas are hot, dry and windy resulting in higher levels of particulate matter including beryllium.

In the historical LLNL particulate data, one of the highest peaks of beryllium particulate matter occurs in the summer months of 2008. To verify that the peak was not caused by LLNL activities, nine archived air filters (COW and MET from S200, and EOBS from S300 collected in January, May and September) were reanalyzed using ICP-MS for a suite of metals. Excellent correlations (Table 2) were found between Be and other metals (including $\mathrm{Al}, \mathrm{Ce}, \mathrm{Co}, \mathrm{Cs}, \mathrm{Fe}, \mathrm{Ga}, \mathrm{K}, \mathrm{Mn}, \mathrm{Ni}, \mathrm{Rb}, \mathrm{Th}, \mathrm{U}, \mathrm{V}$ and many of the rare earth elements). Ten elements were chosen as markers based on their correlation with beryllium in both soil and air samples, namely Al, Cs, Eu, Gd, La, Nd, Pr, Sm, Th and Tl. Europium and gadolinium are found in TV phosphors and alloys (the latter is also used in the manufacture of compact discs). Neodymium and samarium are found in laser components and various alloys (the former is also found in magnets). Praseodymium is found in cigarette lighters, carbon act loams and in coloring of glass and enamel, while thallium is present in rodenticide and ant killing applications. Figure 9 shows that the ratio of Be to these metals did not increase significantly during September, when an increase in beryllium had been observed in the historical data. These results demonstrate that airborne beryllium particles in and around LLNL's S200 and S300 perimeter are not associated with LLNL research activities. The results also show that there is poor correlation between $\mathrm{Be}, \mathrm{Na}$ and industrial metals such as $\mathrm{Zn}$ and $\mathrm{Cu}$, suggesting that beryllium in the local atmosphere is not associated with marine aerosol or industrial manufacturing processes.

The analysis of airborne beryllium particulate matter at LLNL's S200 and S300 indicate negligible impact from LLNL research activities, and suggests that beryllium detected at monitoring stations is from soil resuspension and previous coal fired power station burden.

\subsection{Beryllium entrained in facility carpets}

The distribution of beryllium concentrations found in LLNL facility carpets (both S200 and S300) vacuumed in 2009 is shown in Figure 10a. Facilities (or parts of facilities) known to have beryllium contamination from historical activities were excluded from the study to assess background carpet concentrations. Vacuuming of facility carpets found between 0.002 to $0.480 \mu \mathrm{g} / 100 \mathrm{~cm}^{2}$ Be (mean: $0.080 \mu \mathrm{g} / 100 \mathrm{~cm}^{2}, \sigma: 0.086 \mu \mathrm{g} / 100 \mathrm{~cm}^{2}$, median: $0.053 \mu \mathrm{g} / 100 \mathrm{~cm}^{2}$ ). These values should be compared to the DOE release criterion of $0.2 \mu \mathrm{g} / 100 \mathrm{~cm}^{2}$. In some cases, the beryllium in carpets is above the release criteria with respect to mass per unit area. However, the release criterion does not explicitly consider carpet cleanliness (e.g. dirt loading, age, foot traffic, proximity to exterior door/window, cleaning frequency). Natural beryllium may occur in carpets from tracking of natural soil and deposition of local natural airborne particulates. Processinduced beryllium may occur in carpets due to direct dispersion into the room and subsequent deposition into the carpet, or by tracking beryllium contamination from a 
work area. In comparison, samples taken from the Peek Street Industrial Site, Schenectady, NY (Foley et al., 1994) showed beryllium surface concentration in overhead-collected dust to range from 19.4 to $151 \mu \mathrm{g} / 100 \mathrm{~cm}^{2}$, and floor-level dust ranging from 0.47 to $11.84 \mu \mathrm{g} / 100 \mathrm{~cm}^{2}$. Sanderson et al. (1999) studied beryllium worker contamination in personal vehicles and noted values up to $76.9 \mu \mathrm{g} / 100 \mathrm{~cm}^{2}$. Vincent et al. (2009) sampled 554 surfaces of industrial establishments known to have beryllium processes or materials and found a range of contamination from 0.03 to $805 \mu \mathrm{g} / 100 \mathrm{~cm}^{2}$ (mean: $11.78 \mu \mathrm{g} / 100 \mathrm{~cm}^{2}$, median: $0.075 \mu \mathrm{g} / 100 \mathrm{~cm}^{2}$ ) with the highest levels in industries associated with the manufacture of basic metals, fabricated metal products, medical precision and optical instruments including watches and clocks, and furniture. A study by Day et al. (2007) found beryllium surface levels ranging from 0.05 to 13.60 $\mu \mathrm{g} / 100 \mathrm{~cm}^{2}$ in the front offices and wire annealing/pickling areas respectively of a $\mathrm{Cu}-\mathrm{Be}$ alloy facility. Sanderson (2008) measured Be surface contamination at a munitions plant (some above the 10CFR 850 surface contamination limit of $3.0 \mu \mathrm{g} / 100 \mathrm{~cm}^{2}$ near sanders and grinders) and surrounding reference sites (some above the 10CFR 850 release criteria level of $0.2 \mu \mathrm{g} / 100 \mathrm{~cm}^{2}$, with a maximum of $0.44 \mu \mathrm{g} / 100 \mathrm{~cm}^{2}$ ). These studies clearly indicate that surface contamination existed and that contamination can travel within a facility.

We assessed background beryllium concentrations in background LLNL carpet dirt, with facilities selected based on the lack of known beryllium spills. The results are shown in Figure $10 \mathrm{~b}$, with mass concentrations ranging from 0.15 to $1.9 \mathrm{mg} / \mathrm{kg}$ (mean: $0.38 \mathrm{mg} / \mathrm{kg}$, б: $0.25 \mathrm{mg} / \mathrm{kg}$, median: $0.31 \mathrm{mg} / \mathrm{kg}$ ). The UTL ${ }_{95 \%} \% 5 \%$ was calculated and determined to be $1.10 \mathrm{mg} / \mathrm{kg}$ (Sutton and Lee, 2009). This compares to a maximum of $0.71 \mathrm{mg} / \mathrm{kg}$ for $\mathrm{S} 200$ soil and $2.10 \mathrm{mg} / \mathrm{kg}$ for S300 soil. Higher concentrations were noticed in S300 carpets compared to $\mathrm{S} 200$, which is not surprising given the higher content of beryllium in S300 soil. However, the results suggested that additional beryllium contamination existed in areas of S200 not immediately identified as having known contamination. Samples from facilities known to have contamination ranged from uncontaminated levels to $33 \mathrm{mg} / \mathrm{kg}$ in a room where beryllium powder had been accidentally spilled on the floor.

Subsequently, the dirt loading $\left(\mathrm{g} / 100 \mathrm{~cm}^{2}\right)$ was calculated to gauge how dirty (either natural or process-induced) carpets were. The amount of beryllium in the carpet dirt was then assessed to determine whether soil tracking and deposition could account for the beryllium loading (Sutton and Lee, 2009). In some cases, where dirty old carpets had been cleaned, soluble components of the dirt may be leached into the wash solution, leaving entrained insoluble components (including beryllium) in the carpet and effectively enhancing the natural concentration of beryllium. It was therefore important to compare many of the elemental ratios shown in Table 2 to those measured for carpet samples in an effort to assess the nature of the beryllium. The ten elemental marker ratios selected earlier based on having good correlation coefficients in both LLNL soil and air were compared for each facility. Table 4 shows the Be:M ratios of selected elemental comparative markers for some LLNL facility carpets. Values underlined are greater than the UTL ${ }_{95 \%} 95 \%$ for LLNL soil, while values in italics are greater than the UTL $95 \% 95 \%$ for LLNL air particulates. While it was noted that uranium also had a good correlation with beryllium, it was assumed that the uranium ratios could be biased by historical uranium 
activities at both S200 and S300. Subsequently, uranium was not used as a comparative marker for beryllium contamination. Review of the tabulated results in Table 4 allows a better understanding of the source of beryllium in each facility carpet.

Facilities A and B were indicative of buildings where no historical beryllium activities had been occurring. Particles entrained in carpet inside building A had two elemental markers greater than soil and three markers greater than air. Carpet dirt from building B had three markers greater than soil and one marker greater than air. In each case of elevated ratios, the measured values were less than two times greater than the UTL $95 \% 95 \%$. These exceedences may result from leaching during carpet cleaning, and subsequent enrichment of the remaining insoluble or trapped components of dirt in the carpet; and highlight the importance of using multiple markers in baseline studies.

Facility $\mathrm{C}$ was also a building with no known prior or current beryllium activities occurring inside, while facilities D, E and F were known to house historical beryllium activities and in many cases had known beryllium contamination. Carpet from buildings $\mathrm{C}$ and $\mathrm{E}$ contained dirt that had nine markers greater than soil and nine markers greater than air. Building $\mathrm{C}$ is a multi-floor office building that has no associated historical beryllium activities. Samples taken from other floors in the same facility did not indicated elevated levels of beryllium, and the source of beryllium contamination is unknown. In building E, it is believed that beryllium contamination was tracked from a processing area to the adjacent carpeted sampling location. The carpet in this facility has subsequently been removed. Buildings D and F were known to have elevated concentrations of beryllium due to historical activities and had all ten elemental ratio markers above the soil and air UTL values. Beryllium sputtering activities occurred in building D, and it is believed that elevated levels of beryllium were tracked into the adjacent office. The marker ratios for facility D were typically an order of magnitude above the soil and air UTL, and the carpet has subsequently been removed. Carpet in building F was found to have process-induced beryllium and it is believed tracking from a contaminated work area to the facility carpeted exit occurred. The carpet in facility $F$ has subsequently been removed.

Building $\mathrm{G}$ is located near a beryllium machine shop but the facility itself did not specifically house beryllium activities. Analysis of the 2007 report by Mullins and Kamerzell (2007) found contaminated soil outside the machine shop facility in agreement with data in Dreicer (1985), but it is unlikely that foot traffic through the contaminated soil to the carpet location was responsible. Rather, it is suspected that tracking of beryllium from the neighboring machine shop had occurred (Sutton and Lee, 2009). Building $\mathrm{G}$ had seven markers greater than soil and seven markers greater than air, suggesting tracking did occur from a neighboring contaminated facility, but also suggesting that dispersal from activities in the vicinity did not directly contaminate the carpet.

Building $\mathrm{H}$ did not house beryllium-machining activities, but the facility does house equipment that contains beryllium parts. This facility was chosen for multi-element study because vacuum samples (characterized in terms of mass per surface area and mass per $g$ 
dust) were inconsistent with activities (Sutton and Lee, 2009). The multi-element markers indicate that one location in building $\mathrm{H}$ had all markers below both soil and air, and another location had 10 markers above soil and nine markers above air ratios, a pattern consistent with localized beryllium contamination that has not been tracked to other parts of the building. On closer inspection of the facility, large portions of the carpet had been replaced before the sampling study. A sample taken from the newer carpet $(\mathrm{H}-1)$ fell below the background level, while a sample taken from the older portion of carpet that remained (H-2) indicated localized beryllium contamination. Interestingly, all Be:T1 ratios were above background soil and air particulate data with the exception of the clean carpet in building $\mathrm{H}$.

While having one marker above the UTL might indicate beryllium contamination, it does not screen for interferences from high background. Therefore, having more than three marker ratios above UTL $95 \% 95 \%$ in a carpet samples appears to positively identify beryllium contamination based on our results. The number and magnitude of marker ratio exceedences can be used to assess both the existence and degree of contamination and the subsequent effectiveness of the restoration, but the exact number and magnitude may vary from site to site.

\section{Conclusions}

This study established a new value for background beryllium in LLNL main site (S200) soils. Beryllium in S200 soil is typical in both concentration and its correlation to other metals of local and US soils. Soil at LLNL S300 contains a higher level of beryllium compared to LLNL S200, likely due to the difference in soil type between the two sites.

Analysis of historical air filters have shown that LLNL beryllium activities have had negligible impact on the Be content of airborne particulate matter in and around LLNL's main campus and annex facility. Seasonal variations in airborne beryllium levels are due to local meteorological phenomena (dry, hot, windy weather in the summer/fall months) and burden from both global resuspension of soil and/or coal fired power stations. The EPA's Clean Air Act had a significant impact on the reduction of beryllium associated with inhalable particulate matter (specifically PM10). The results may be used to evaluate the timing of outdoor activities for those individuals already sensitized to beryllium who have an increased likelihood of developing chronic beryllium disease from inhalation of beryllium.

Multi-element analysis of archived soil samples showed Be:M ratios for correlated metals at or below national soils measured by the USGS. This technique provides useful information in determining the nature and source of beryllium in future environmental and industrial hygiene samples and allows the exclusion of other environmental impacts such as industrial contamination. Be:M ratios provided additional information on the source of beryllium found in carpets located in both beryllium processing areas and areas free from beryllium activities. In some cases, with additional information on historical beryllium activities, it is possible to distinguish between direct (intra-facility) 
contamination and tracked (inter-facility) contamination based on the number of Be:M ratios exceeding the natural background levels. It is recommended that other berylliumhandling facilities use multi-element analysis and multiple elemental marker ratios as a confirmatory tool to supplement current beryllium surveillance activities in cases where suspected elevated beryllium results are generated from traditional analysis. Since atmospheric dust can be affected by nearby emissions and soil composition varies by region, it is recommended that local, regional and national uncontaminated samples be analyzed or sought to help distinguish between natural and process-induced beryllium in the workplace and environment. The results of such studies should be compared to this study and USGS data referenced here to assess the relevance of international data.

\section{Acknowledgements}

The authors greatly appreciate the historical information provided by Dave Zalk and Ryan Kamerzell at LLNL; and acknowledge Reggie Gaylord and Gretchen Gallegos for their support of this work.

This work was performed under the auspices of the U.S. Department of Energy by Lawrence Livermore National Laboratory under Contract DE-AC52-07NA27344. This document was prepared as an account of work sponsored by an agency of the United States government. Neither the United States government nor Lawrence Livermore National Security, LLC, nor any of their employees makes any warranty, expressed or implied, or assumes any legal liability or responsibility for the accuracy, completeness, or usefulness of any information, apparatus, product, or process disclosed, or represents that its use would not infringe privately owned rights. Reference herein to any specific commercial product, process, or service by trade name, trademark, manufacturer, or otherwise does not necessarily constitute or imply its endorsement, recommendation, or favoring by the United States government or Lawrence Livermore National Security, LLC. The views and opinions of authors expressed herein do not necessarily state or reflect those of the United States government or Lawrence Livermore National Security, LLC, and shall not be used for advertising or product endorsement purposes. LLNLJRNL-553831.

\section{References}

Aelion CM, Davis HT, McDermott S, Lawson AB. Metal concentrations in rural topsoil in South Carolina: Potential for human health impact. Science of the Total Environment 2008; 402: 149-156.

Aelion CM, Davis HT, McDermott S, Lawson AB. Soil metal concentrations and toxicity: Associations with distances to industrial facilities and implications for human health. Science of the Total Environment 2009; 407: 2216-2223.

Anderson MA, Bertsch PM, Miller WP. Beryllium in selected southeastern soils. Journal of Environmental Quality 1990; 19: 347-348. 
ATSDR-CDC. Toxicological Profile for Beryllium. Agency for Toxic Substances and Disease Registry, US Department of Health and Human Services (http://www.atsdr.cdc.gov), 2002.

ASTM. Standard Practice for Collection of Floor Dust for Chemical Analysis. Method D5438-05. American Society for Testing and Materials, 2005.

Azahra M, Lopez-Penalver JJ, Camacho-Garcia MA, Gonzelez-Gomez C, El Bardouni T, Boukhal H. Atmospheric concentrations of Be-7 and Pb-210 in Granada, Spain. Journal of Radioanalytical and Nuclear Chemistry 2004; 261: 401-405.

BAAQMD. Regulation 11, Rule 3, Beryllium. Bay Area Air Quality Management District (http://www.baaqmd.gov/), 1982.

Bohn HL. Soil Absorption of Air Pollutants. J. Environ. Qual. 1972; 1: 372-377. Bowen HJM. Trace Elements in Biochemistry: Academic Press (New York), 1966.

Canova JL. Elements in South Carolina inferred background soil and stream sediment samples. South Carolina Geology Journal 1999; 41: 11-25.

Day GA, Dufresne A, Stefaniak AB, Schuler CR, Stanton ML, Miller WE, et al. Exposure pathway assessment at a copper-beryllium alloy facility. Annals of Occupational Hygiene 2007; 51: 67-80.

Doering C, Akber R. Beryllium-7 in near-surface air and deposition at Brisbane, Australia. Journal of Environmental Radioactivity 2008; 99: 461-467.

Dreicer M. Preliminary report on the past and present uses, storage, and disposal of hazardous materials and wastes at the Lawrence Livermore National Laboratory. Lawrence Livermore National Laboratory (UC-ID 20442), 1985, pp. 242.

Drury JS, Shriner CR, Lewis EB, Towill LE, Hammons A. Reviews on the Environmental Effects of Pollutants: VI. Beryllium. Oak Ridge National Laboratory ORNL/EIS-87, EPA-600-1/78-028, 1978.

Feely HW, Larsen RJ, Sanderson CG. Factors that cause seasonal variations in beryllium-7 concentrations in surface air. Journal of Environmental Radioactivity 1989; 9: 223-249.

Fishbein L. Sources, Transport and Alterations of Metal-Compounds - an Overview .1. Arsenic, Beryllium, Cadmium, Chromium, and Nickel. Environmental Health Perspectives 1981; 40: 43-64.

Foley RD, Allred JF, Carrier RF. Supplementary Radiological and Beryllium Characterization of the Facility at 425 Peek Street, Schenectady; New York. Oak Ridge National Laboratory ORNL-6623/Suppl, 1994.

Gluskoter HJ, Ruch RR, Miller WG, Cahill RA, Dreher GB, Kuhn JK. Trace Elements in Coal: Occurrence and Distribution. Illinois State Geological Survey, Circular 499, 1977.

Gran T, Word W. Determination of Natural Beryllium in Soil and Swipe Samples Utilizing Yttrium/Beryllium Ratio (Abstract P0127-9). AIHce 2011 (May 1419th 2011; Portland, OR) 2011.

Heindl RA. Mineral Facts and Problems: Beryllium. US Bureau of Mines Bulletin 650, 1970, pp. 489-501.

Hormann PK. Beryllium. In: Wedopohl KH, editor. Handbook of Geochemistry. Springer-Verlag, New York, 1969, pp. II/1, 4D1-407. 
Jones HE, Armstrong D, Gallegos G, Paterson L, Blake R, Grayson AR, et al. Lawrence Livermore National Laboratory 2010 Environmental Report. Lawrence Livermore National Laboratory UCRL-TR-50027-10 2011, pp. 181.

Kubiznakova J. Beryllium pollution from slag and ashes from thermal powerstations. Water Air and Soil Pollution 1987; 34: 363-367.

LANL. Environmental Surveillance at Los Alamos During 2000. Los Alamos National Laboratory Report LA-13861-ENV, 2001, pp. 531.

Mullins JC, Kamerzell RG. Determination of naturally occurring versus process introduced beryllium at Lawrence Livermore National Laboratory. Lawrence Livermore National Laboratory (UCRL-JRNL-234076), 2007, pp. 20.

Neal C. Dissolved and acid available particulate beryllium in eastern UK surface waters. Science of the Total Environment 2003; 314: 185-208.

Oatts TJ, Hicks CE, Adams AR, Brisson MJ, Youmans-McDonald LD, Hoover MD et al. Preparation, certification and interlaboratory analysis of workplace air filters spiked with high-fired beryllium oxide. J. Environ. Monit. 2012; 14: 391-401.

Ogurek AG. Source and pathway determination for beryllium found in Bechtel Nevada North Las Vegas facilities. Bechtel Nevada Beryllium Investigation \& Assessment Team (DOE/NV/11718-953), 2004, pp. 37.

Ondov JM, Ragaini RC, Biermann AH. Emissions and Particle-Size Distributions of Minor and Trace-Elements at 2 Western Coal-Fired Power-Plants Equipped with Cold-Side Electrostatic Precipitators. Environmental Science \& Technology 1979; 13: 946-953.

OSHA. 29 CFR 1910.1000: Occupational Safety and Health Standards - Air Contaminants. (Available online at http://www.osha.gov/pls/oshaweb/owadisp.show_document?p_table=STA NDARDS\&p_id=9992) US Occupational Safety and Health Administration, 1999.

Patton SE. Beryllium in soils of the Nevada Test Site: a preliminary assessment. Lawrence Livermore National Laboratory UCRL-ID-104740, 1992, pp. 25.

Romney EM, Childress JD. Effects of Beryllium in Plants and Soil. Soil Science 1965; 100: 210-217.

Ruch RR, Gluskoter HJ, Shimp NF. Occurrence and distribution of potentially volatile trace elements in coal : final report. Illinois State Geological Survey Environmental Geology Notes 72, 1974.

Sanderson WT, Henneberger PK, Martyny J, Ellis K, Mroz MM, Newman LS. Beryllium contamination inside vehicles of machine shop workers. American Journal of Industrial Medicine 1999: 72-74.

Sanderson WT, Leonard S, Ott D, Fuortes L, Field W. Beryllium surface levels in a military ammunition plant. Journal of Occupational and Environmental Hygiene 2008; 5: 475-481.

Shacklette HT, Boerngen JG. Element concentrations in soils and other surficial materials of the conterminous United States. US Geological Survey Professional Paper 1270, 1984, pp. 63.

Shireman J, Mayila AS, Bradley CK, Allen MS. Statistical Analysis of the Occurrence of Beryllium in Soils at Naval Air Station Moffett Field. In: Kostecki PT, editor. 
Hydrocarbon Contaminated Soils, Vol. V, Ch. 9. Amherst Scientific Publishers, Amherst, MA, 1995, pp. 93-131.

Smith DB, Cannon WF, Woodruff LG, Garrett RG, Klassen R, Kilburn JE, et al. Majorand Trace-Element Concentrations in Soils from Two Continental-Scale Transects of the United States and Canada. Open-File Report 2005-1253, U.S. Geological Survey. U.S. Geological Survey Open-File Report 2005-1253, 2005.

Sutton M, Burastero SR. Beryllium chemical speciation in elemental human biological fluids. Chemical Research in Toxicology 2003; 16: 1145-1154.

Sutton M, Lee S. Evaluation of Carpet Sampling Data: Beryllium Source Term Evaluation - Final Report. Lawrence Livermore National Laboratory (LLNLAR-418626), 2009, pp. 14.

Taiwo OA, Slade MD, Cantley LF, Kirsche SR, Wesdock JC, Cullen MR. Prevalence of beryllium sensitization among aluminium smelter workers. Occupational Medicine-Oxford 2010; 60: 569-571.

Taylor TP, Ding M, Ehler DS, Foreman TM, Kaszuba JP, Sauer NN. Beryllium in the environment: A review. Journal of Environmental Science and Health Part aToxic/Hazardous Substances \& Environmental Engineering 2003; 38: 439469.

Tepper LB, VanOrdstrand HS. Beryllium. Critical Reviews in Toxicology 1972; 1 : 235-259.

Thorat DD, Mahadevan TN, Ghosh DK, Narayan S. Beryllium concentrations in ambient air and its source identification. Environmental Monitoring and Assessment 2001; 69: 49-61.

Tinkle SS, Antonini JM, Rich BA, Roberts JR, Salmen R, DePree K, et al. Skin as a route of exposure and sensitization in chronic beryllium disease. Environmental Health Perspectives 2003; 111: 1202-1208.

USDA. National Cooperative Soil Characterization Database (Available online at http://ncsslabdatamart.sc.egov.usda.gov). National Cooperative Soil Survey 2008.

USDOE. 10 CFR Part 850: Department of Energy Chronic Beryllium Disease Prevention Program; Final Rule. Federal Register 1999; 64(235): 6885468914.

USDOE. Energy Employees Occupational Illness Compensation Act of 2000: List of Covered Facilities. DOE Federal Register Notice, 6450-01-p; Vol 75 No.226, November 24, 2010; 71737-7174,, 2010.

USEPA. Clean Air Act Amendments of 1990 ( Pub. L. No. 101-549, 104 Stat. 2399, codified at 42 U.S.C. 7401-7671q; http://www.epa.gov/air/caa/). U.S. Environmental Protection Agency, 1990.

USEPA. Hazard Ranking System Documentation Record: Franklin Slag Pile (MDC) Site, Philadelphia County, Pennsylvania (http://www.epa.gov/superfund/sites/docrec/pdoc1644.pdf). U. S. Environmental Proctection Agency SFUND-2001-0009-0008, 2001.

USEPA. Particulate Matter: Air Trends - PM10 Air Quality 1990-2010 (http://www.epa.gov/airtrends/pm.html). U. S. Environmental Protection Agency, 2012. 
USGAO. US Locations Where Beryllium Was Used or Detected. United States General Accounting Office GA0-01-476R ( http://www.gao.gov/products/GAO-01476R), 2001, pp. 21.

Winchester MR, Turk GC, Butler TA, Oatts TJ, Coleman C, Nadratowski D et al. Certification of beryllium mass fraction in SRM 1877 beryllium oxide powder using high-performance inductively coupled plasma optical emission spectrometry with extract matching. Anal. Chem. 2009; 81: 2208-2217.

Yamamoto M, Sakaguchi A, Sasaki K, Hirose K, Igarashi Y, Kim CK. Seasonal and spatial variation of atmospheric $\mathrm{Pb}-210$ and Be-7 deposition: features of the Japan Sea side of Japan. Journal of Environmental Radioactivity 2006; 86: 110-131. 
Figures

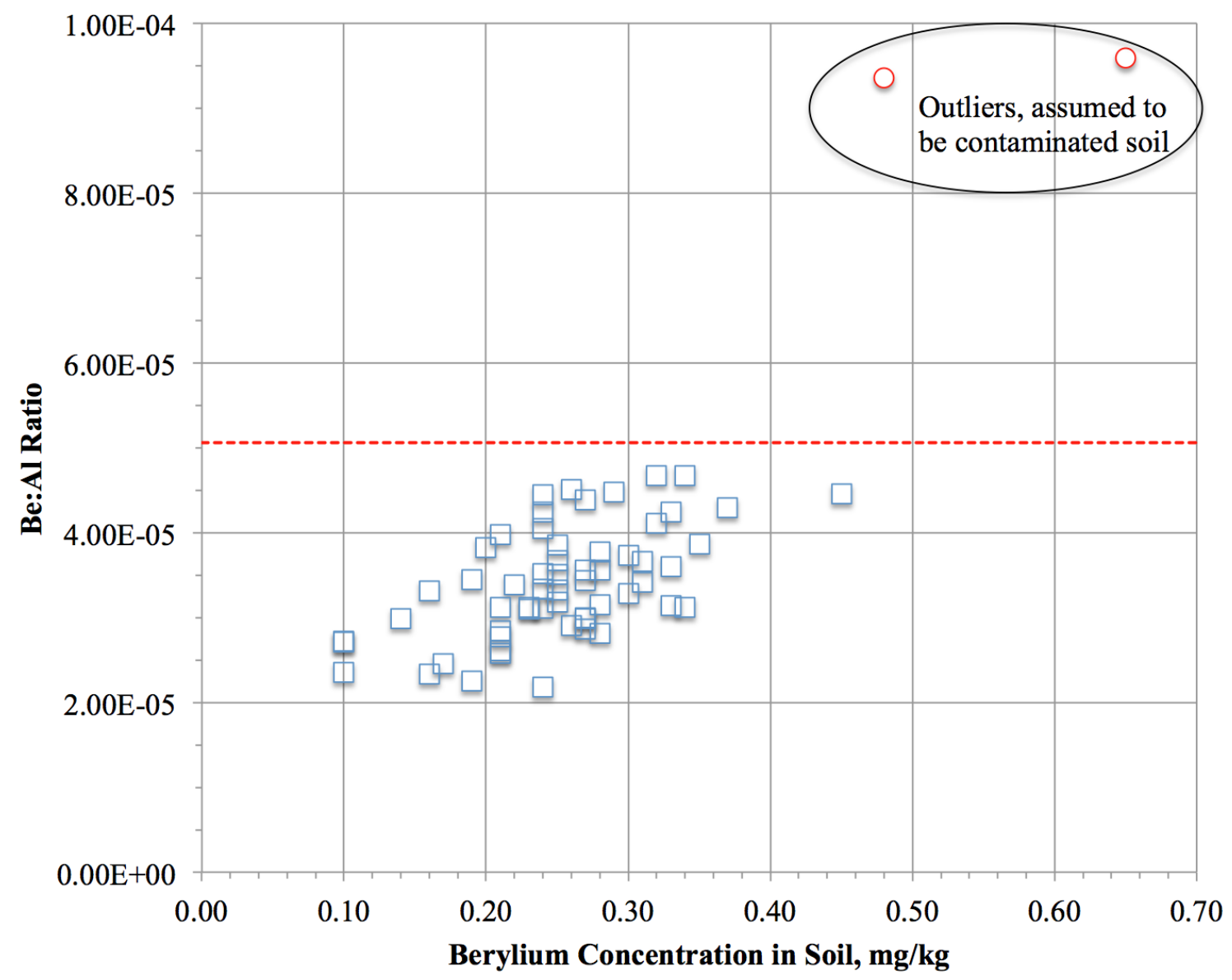

Figure 1. Beryllium and aluminum concentrations for 60 S200 soil samples analyzed in 2007 (Mullins and Kamerzell, red circles considered outliers using a UTL $95 \%, 95 \%=5.07$ $\mathrm{x} 10^{-5}$, red dashed line) 


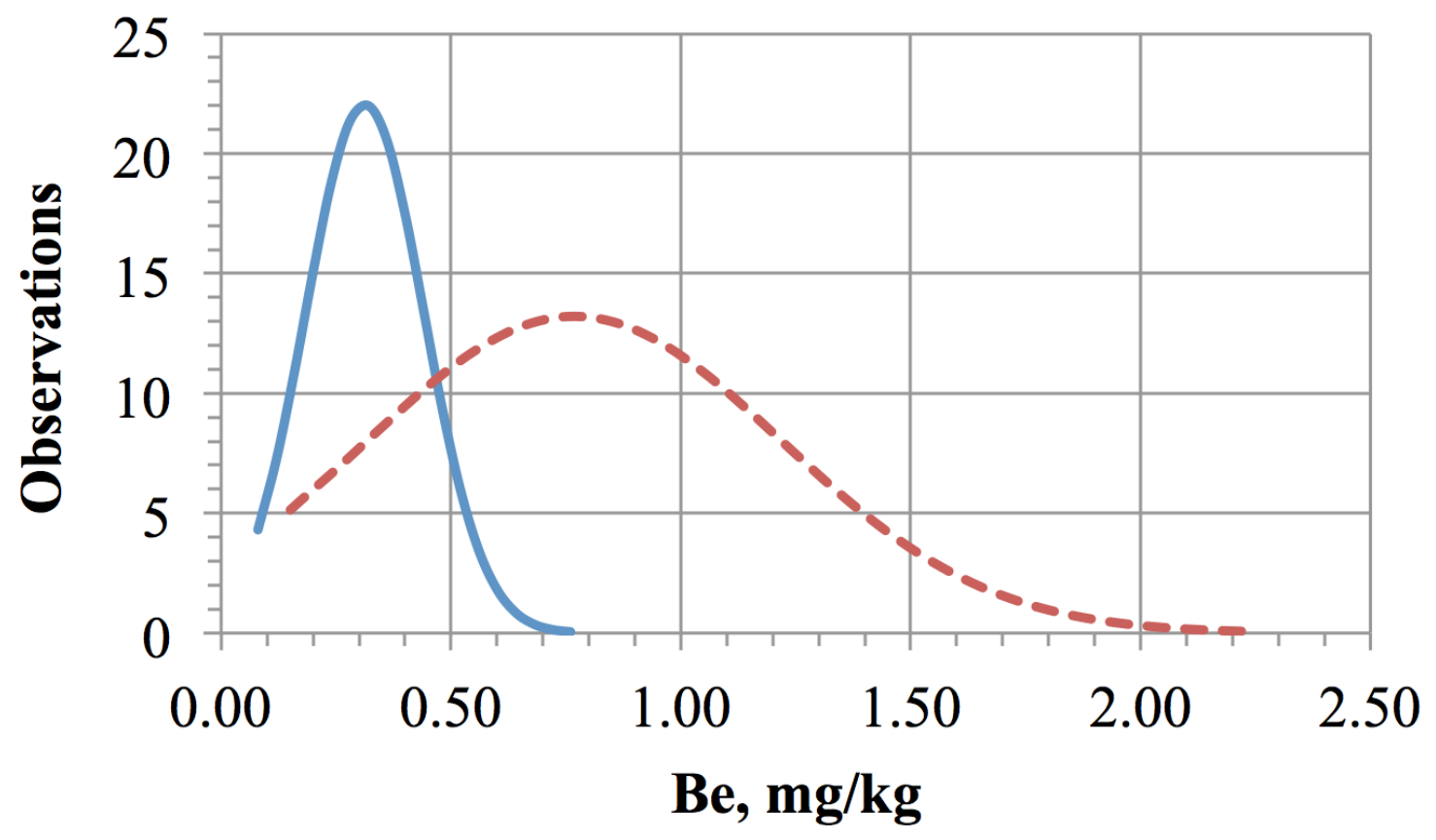

Figure 2. Beryllium concentrations in soil at LLNL's S200 (blue solid line) and S300 (red dashed line) from 1988-2010, (S200 blue solid line, S300 red dotted line) 


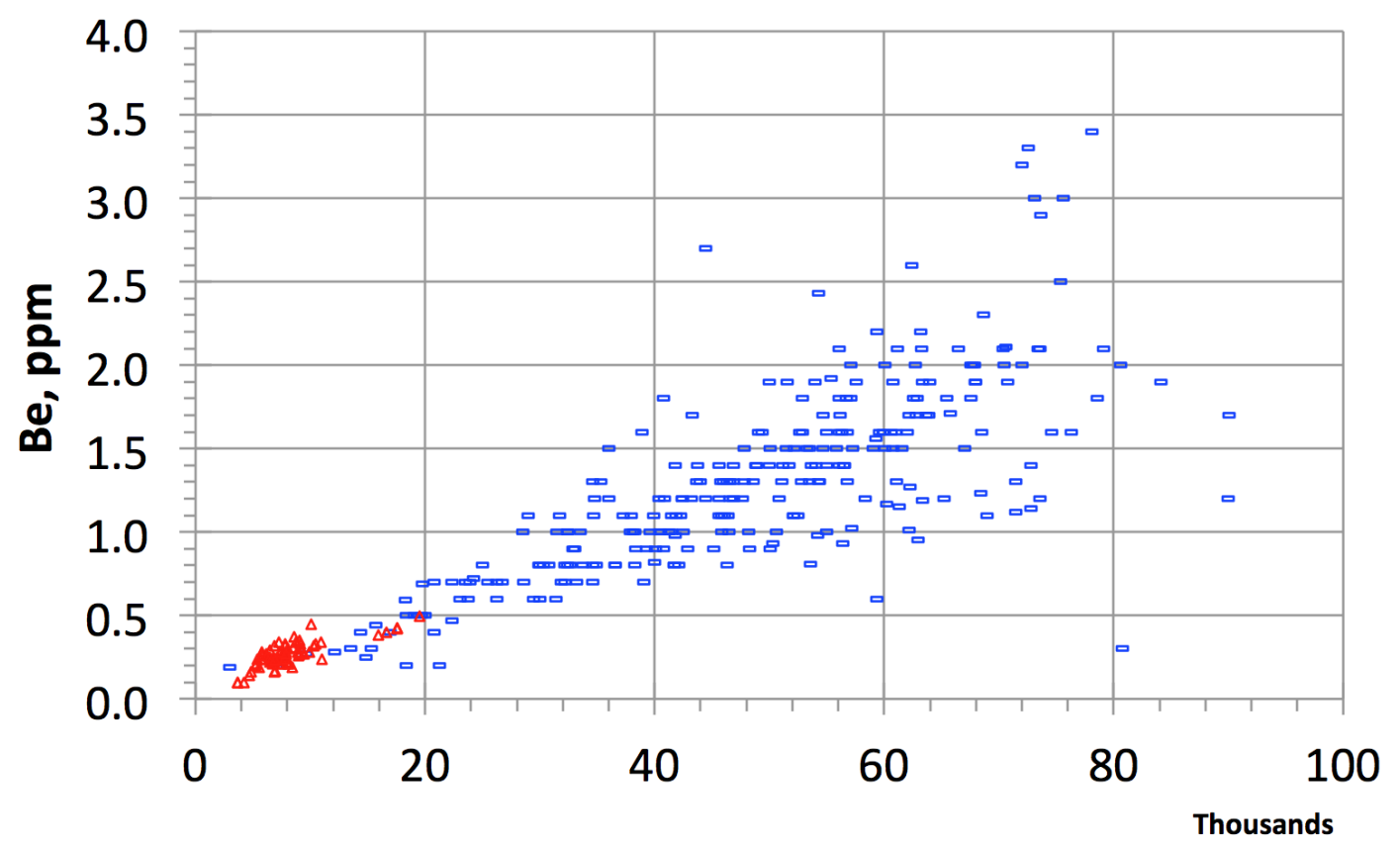

Al, ppm

Figure 3. Beryllium correlation with aluminum in LLNL S200 soil samples (red triangle) overlaid on USGS national data soil composition data (Smith et al 2005, blue rectangle) 


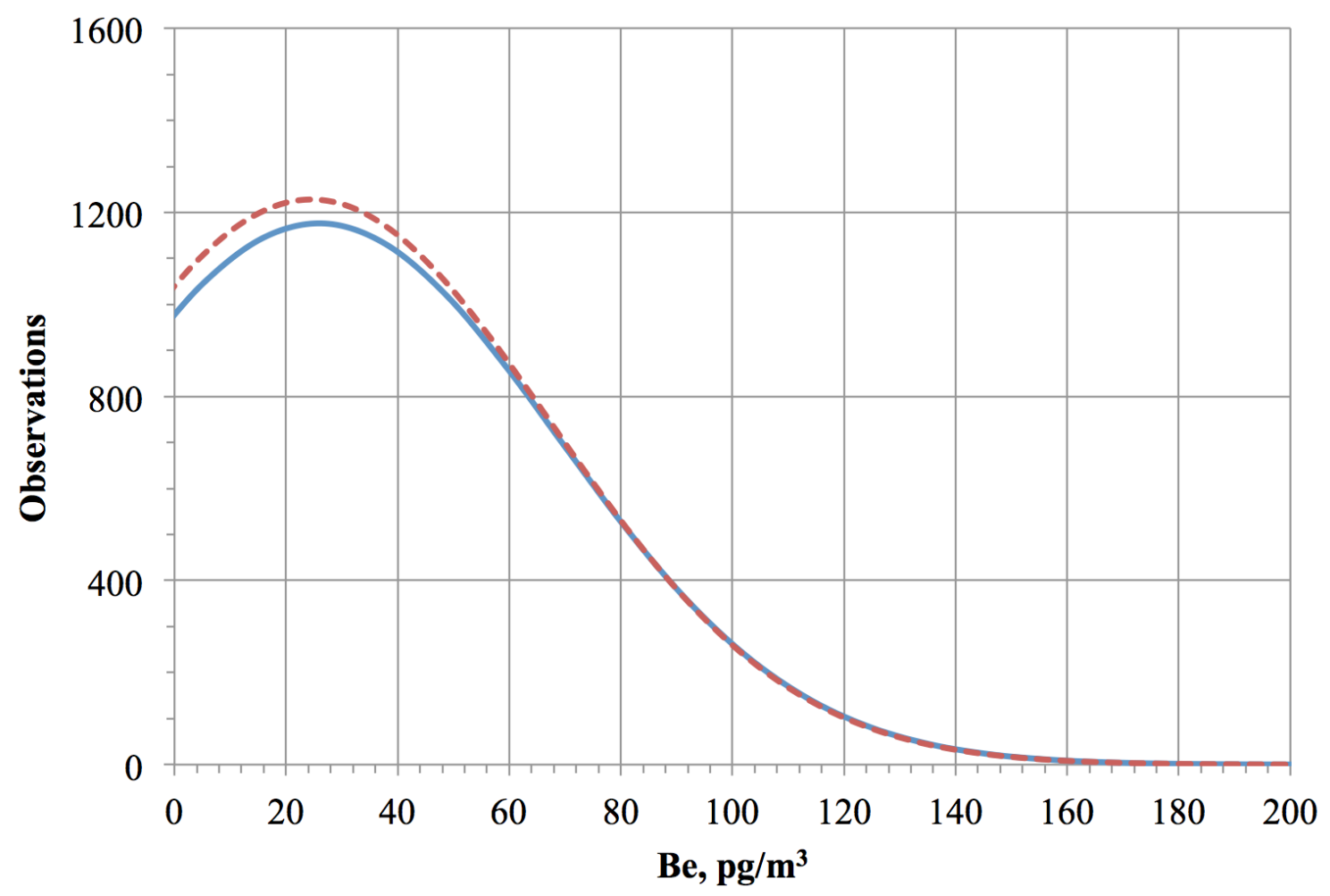

Figure 4. Historical beryllium airborne particulate concentrations at LLNL's S200 (blue solid line) and S300 (red dashed line) from 1974-2010 and 1981-2010 respectively 


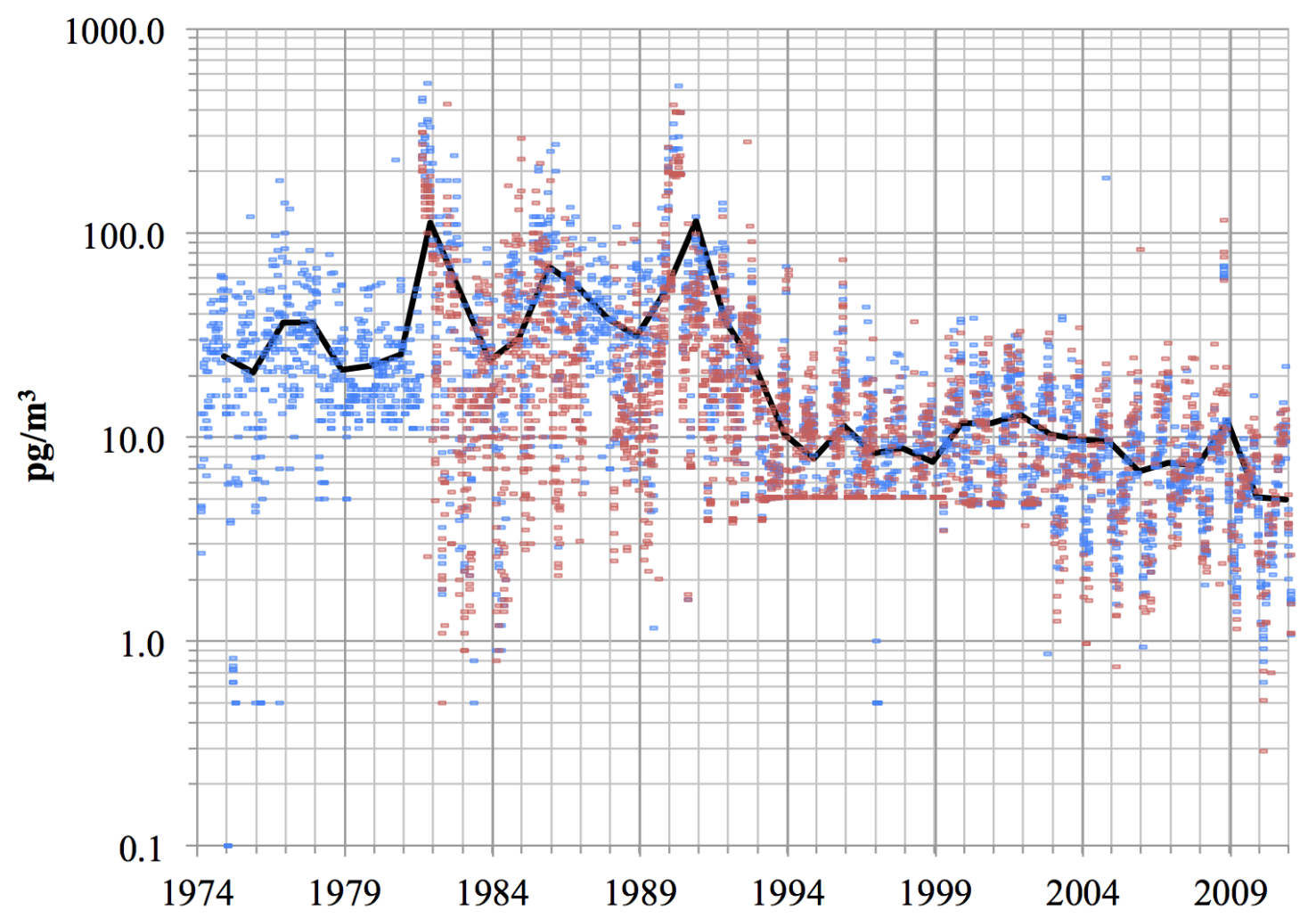

Figure 5. Historical beryllium concentration in monthly sampled airborne particulates (pg $\mathrm{Be} / \mathrm{m}^{3}$ ) at LLNL's S200 (blue), S300 (red) and average annual concentrations (black) from 1974 to 2010 


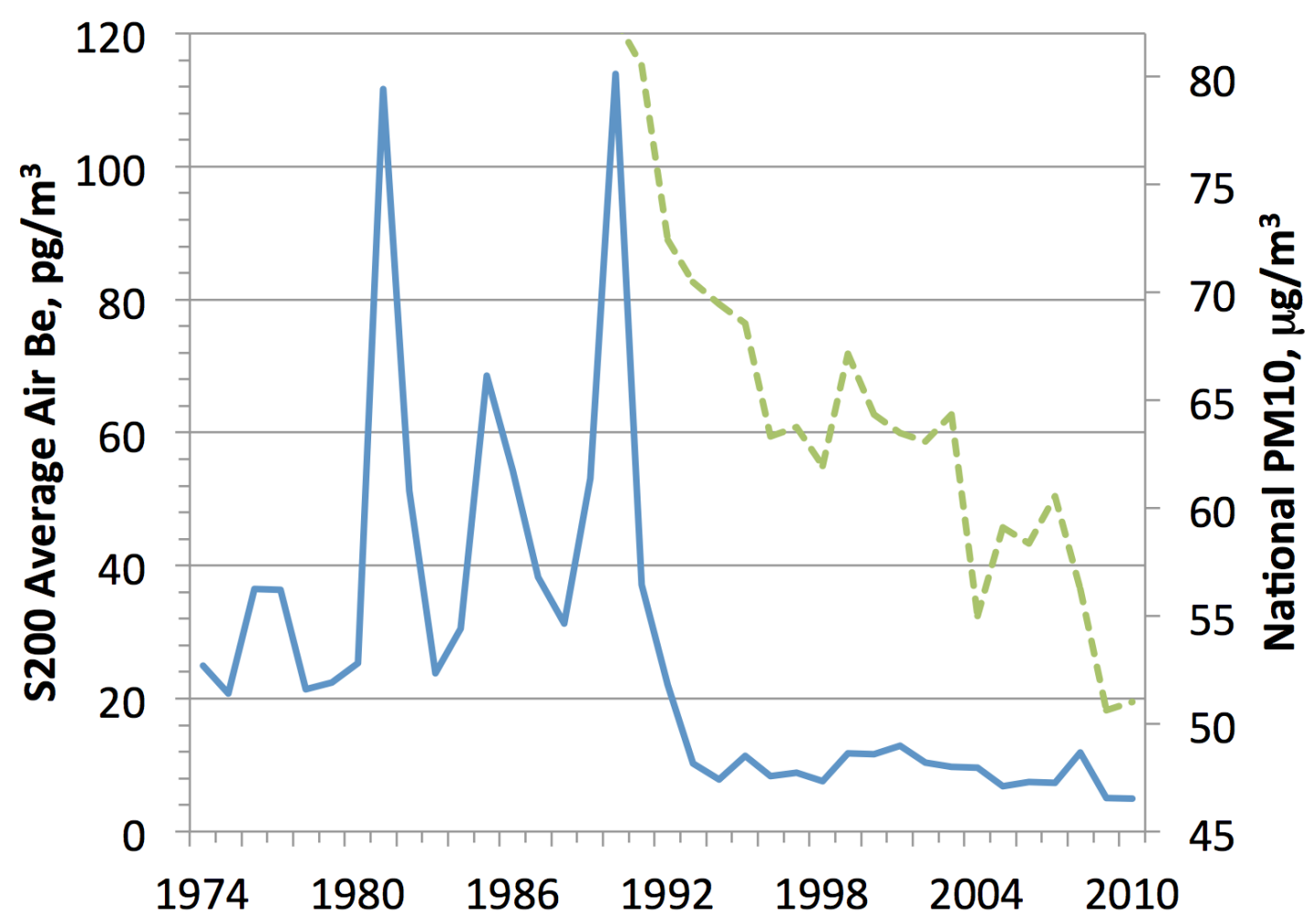

Figure 6. Average annual beryllium concentration in airborne particulates at LLNL (from 1974 to 2010, solid blue line) and national annual PM10 (from 1992 to 2010, EPA 2012, dashed green line) 

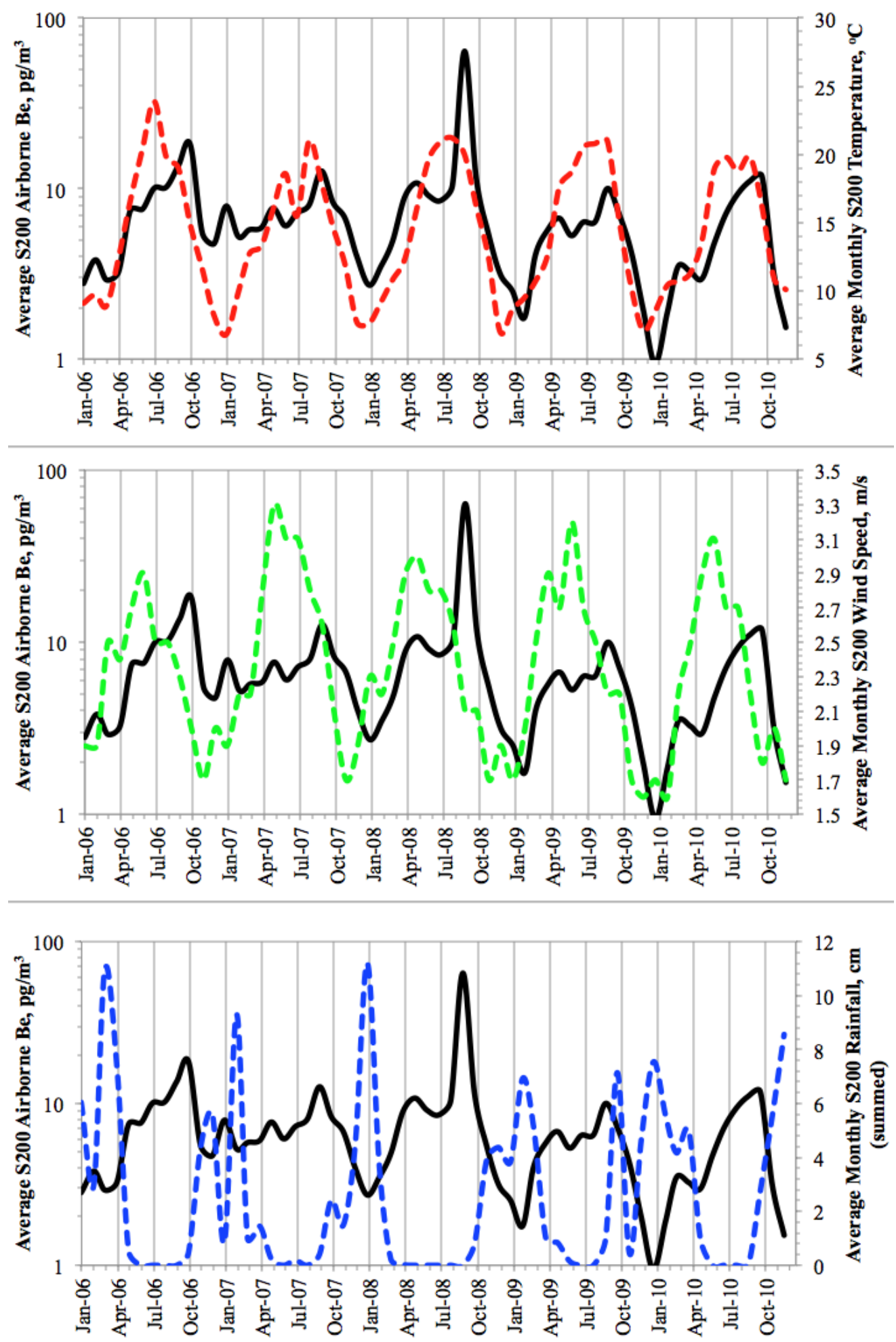

Figure 7. Monthly LLNL beryllium airborne particulate concentration (solid black line), shown with average monthly temperature (red dashed line), wind speed (dashed green line) and summed rainfall (dashed blue line) for S200 from 2006 to2010 


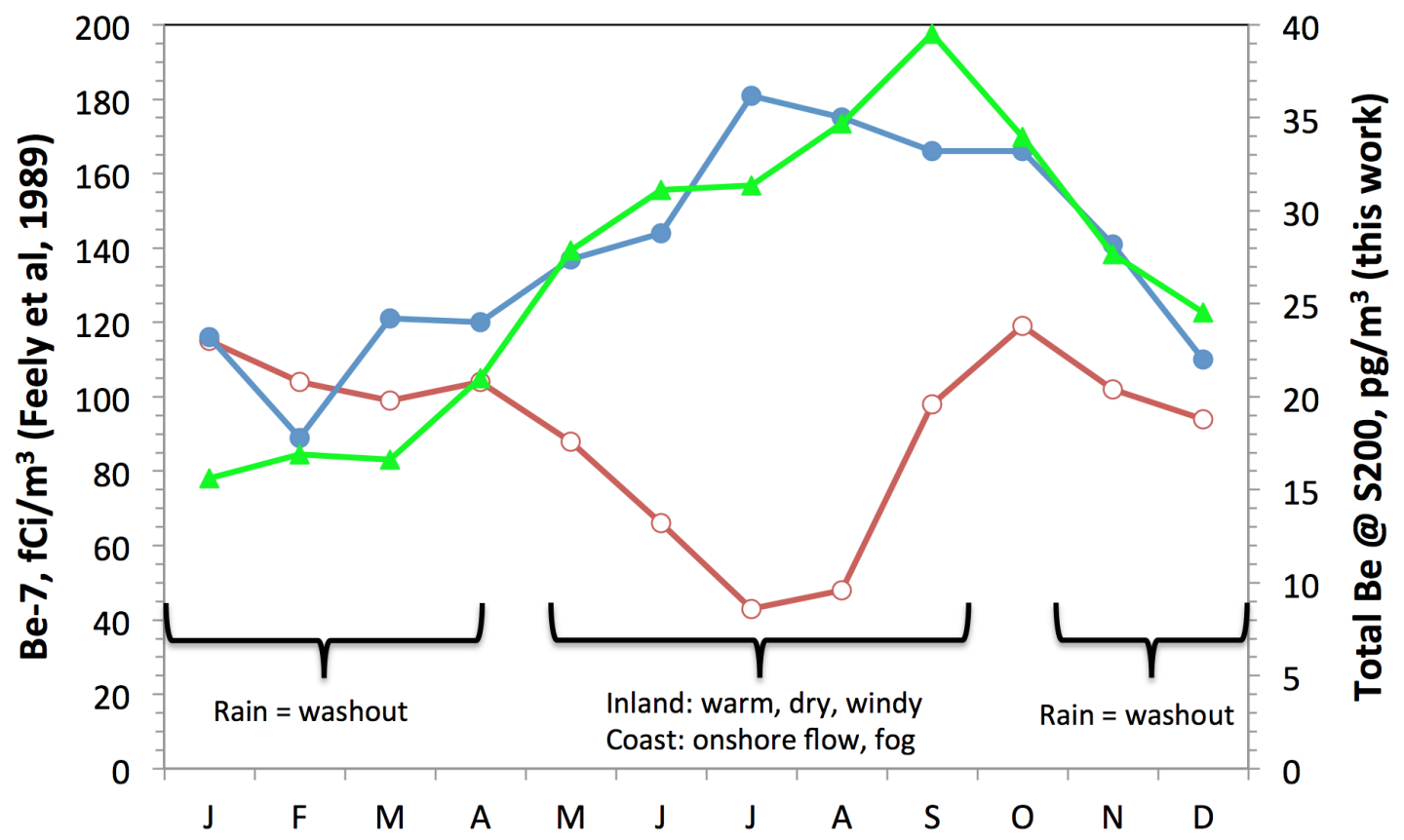

Figure 8. Monthly LLNL beryllium airborne particulate concentration from 1973 to 1980 (solid green line / triangle points), overlaid on local Be-7 (Feely et al 1989) measurements from Richmond, CA (1973 to 1977, red dashed line / open circle points) and Tracy, CA (1977 to 1981, blue dotted line / full circle points) 


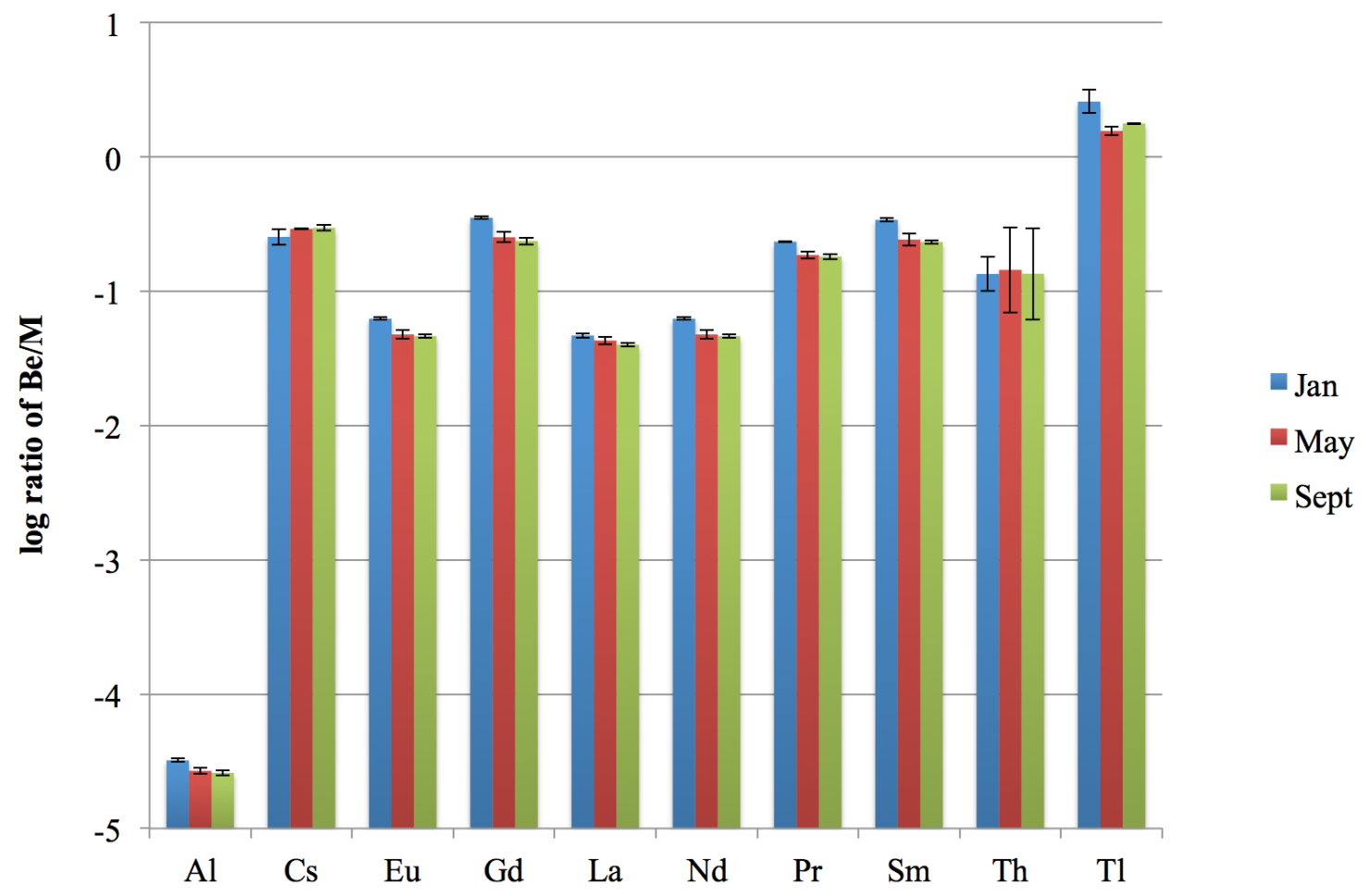

Figure 9. Winter, spring and summer ratios of $\mathrm{Be} / \mathrm{M}$ in airborne particulates collected at LLNL during 2008 


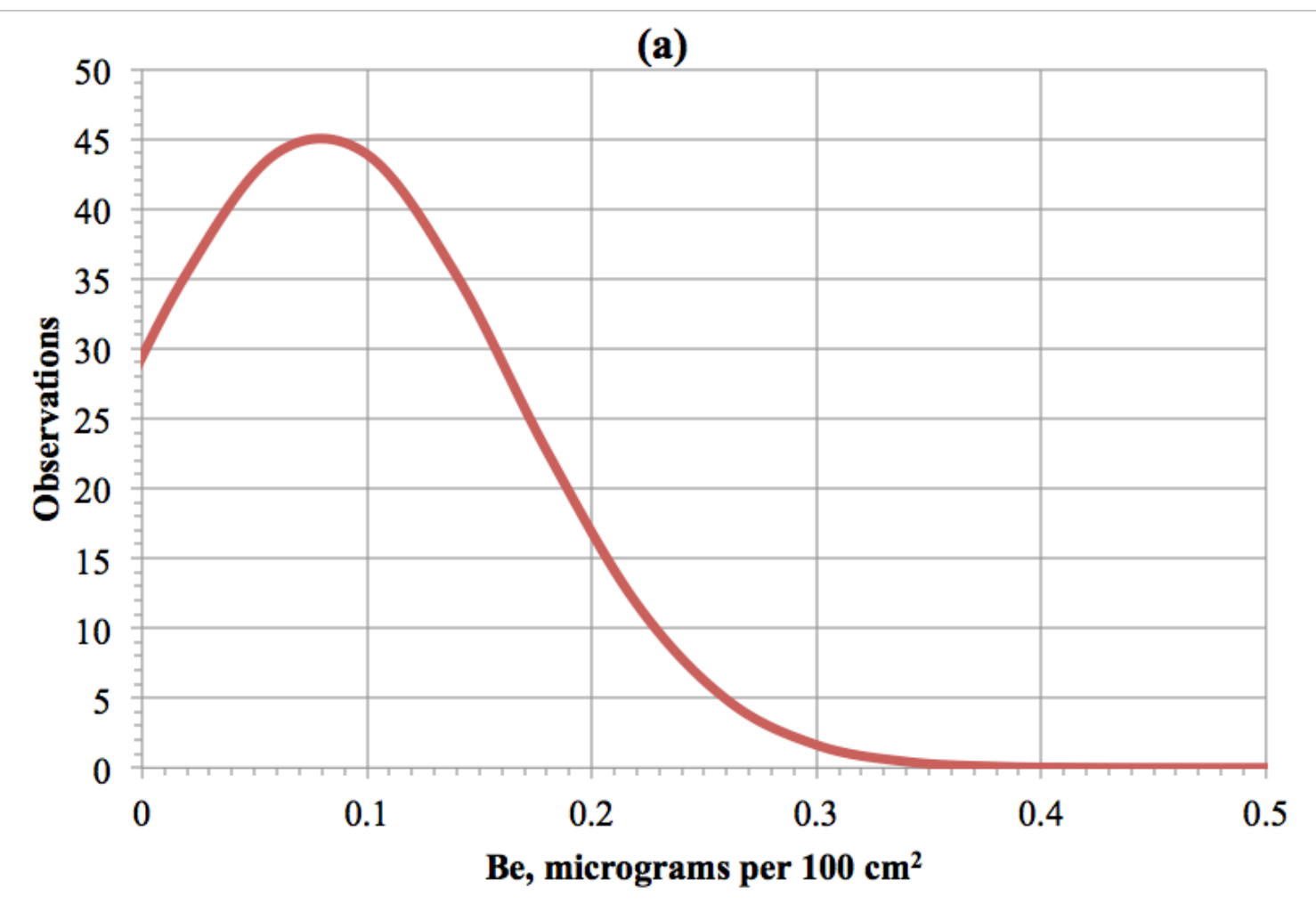

(b)

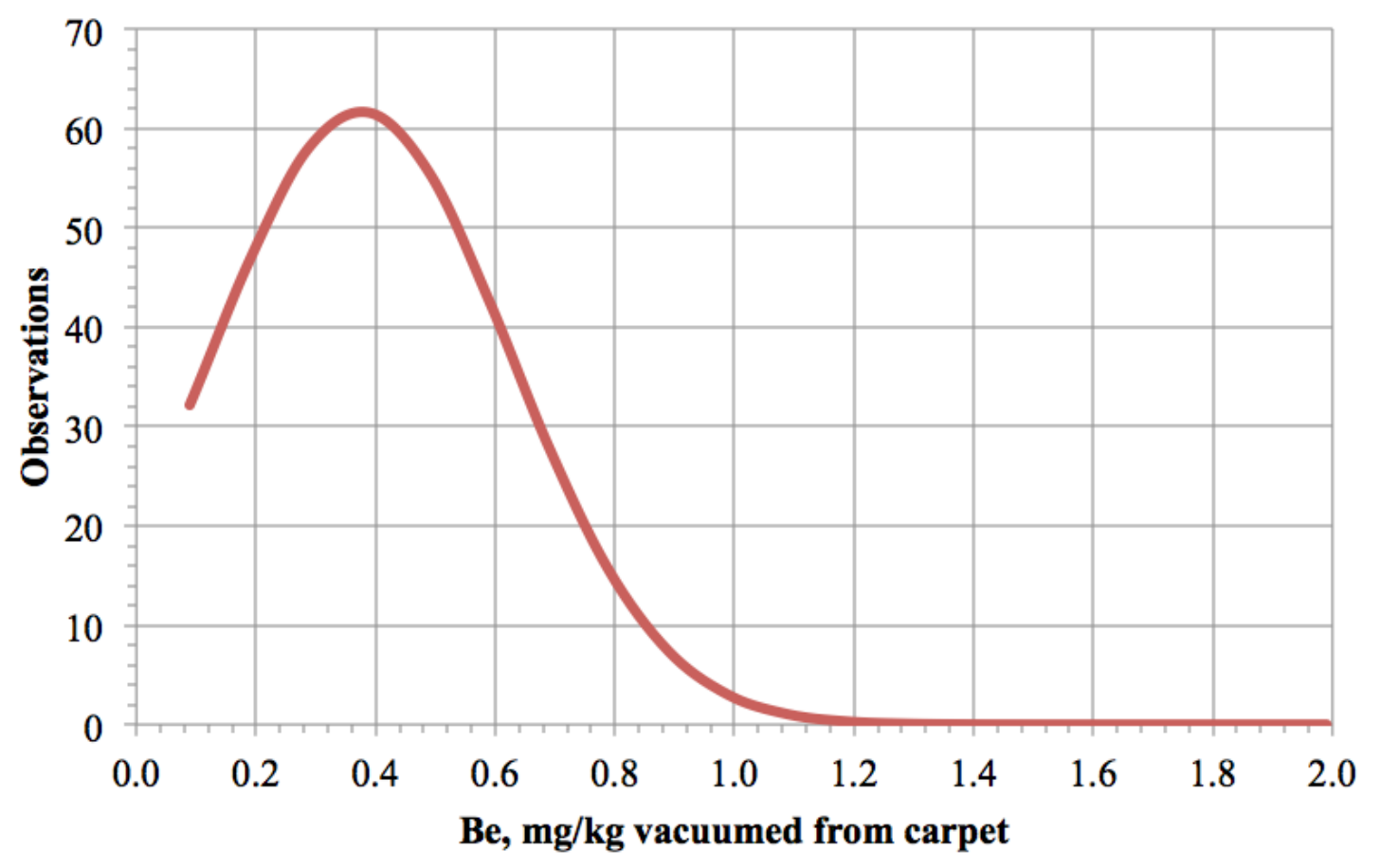

Figure 10. Beryllium concentrations found in LLNL facility carpets during 2009 


\section{Tables}

Table 1. Statistical data for beryllium in soil at LLNL S200 and S300 (mg/kg)

\begin{tabular}{l|rr} 
& $\mathrm{S} 200$ & $\mathrm{~S} 300$ \\
\hline Years Sampled & $1988-1994,2007$ & $1991-2010$ \\
$\mathrm{~N}$ & 87 & 60 \\
Range & $0.10-0.71$ & $0.20-2.10$ \\
Mean & 0.31 & 0.79 \\
Standard deviation & 0.13 & 0.48 \\
Median & 0.28 & 0.68
\end{tabular}


Table 2. UTL $95 \% 95 \%$ and correlation coefficient (R) for the ratio of beryllium to metal concentrations found in national and local soil and air samples

\begin{tabular}{|c|c|c|c|c|c|c|c|c|}
\hline \multirow[t]{2}{*}{ Be:M Ratio } & \multicolumn{2}{|c|}{ USGS Soil $^{\mathrm{a}}$} & \multicolumn{2}{|c|}{ Mullins LLNL Soil ${ }^{b}$} & \multicolumn{2}{|c|}{ LLNL Soil $^{\mathrm{c}}$} & \multicolumn{2}{|c|}{ LLNL Air $^{d}$} \\
\hline & UTL $_{95 \% 95 \%}$ & $\mathrm{R}$ & UTL $_{95 \% 95 \%}$ & $\mathrm{R}$ & UTL $_{95 \% 95 \%}$ & $\mathrm{R}$ & UTL $_{95 \% 95 \%}$ & $\mathrm{R}$ \\
\hline $\mathrm{Ag}$ & - & - & - & - & $7.24 \mathrm{E}+00$ & 0.55 & - & - \\
\hline $\mathrm{Al}$ & $5.90 \mathrm{E}-05$ & 0.77 & $4.73 \mathrm{E}-05$ & 0.70 & $2.04 \mathrm{E}-05$ & 0.72 & $3.76 \mathrm{E}-05$ & 1.00 \\
\hline As & - & - & - & - & $2.55 \mathrm{E}-01$ & 0.14 & $1.90 \mathrm{E}-02$ & 0.25 \\
\hline $\mathrm{Ba}$ & $4.67 \mathrm{E}-09$ & 0.34 & $2.23 \mathrm{E}-03$ & 0.53 & $2.02 \mathrm{E}-03$ & 0.12 & $2.24 \mathrm{E}-03$ & 0.76 \\
\hline $\mathrm{Ca}$ & $1.04 \mathrm{E}-03$ & -0.01 & - & - & $1.39 \mathrm{E}-04$ & -0.74 & $3.68 \mathrm{E}-05$ & 0.88 \\
\hline $\mathrm{Cd}$ & - & - & - & - & $4.53 \mathrm{E}-01$ & -0.20 & $2.91 \mathrm{E}-01$ & 0.60 \\
\hline $\mathrm{Ce}$ & $5.37 \mathrm{E}-08$ & 0.73 & - & - & $3.61 \mathrm{E}-02$ & 0.50 & $2.88 \mathrm{E}-02$ & 0.99 \\
\hline $\mathrm{Co}$ & $5.08 \mathrm{E}-07$ & -0.02 & - & - & $1.32 \mathrm{E}-01$ & 0.08 & $7.66 \mathrm{E}-02$ & 0.97 \\
\hline $\mathrm{Cr}$ & $1.64 \mathrm{E}-07$ & -0.15 & - & - & $2.17 \mathrm{E}-02$ & -0.33 & $8.96 \mathrm{E}-03$ & 0.90 \\
\hline $\mathrm{Cs}$ & $1.20 \mathrm{E}-06$ & 0.75 & - & - & $5.66 \mathrm{E}-01$ & 0.86 & $3.65 \mathrm{E}-01$ & 0.99 \\
\hline $\mathrm{Cu}$ & $3.09 \mathrm{E}-07$ & 0.19 & $2.69 \mathrm{E}-02$ & -0.01 & $5.92 \mathrm{E}-02$ & -0.47 & $4.74 \mathrm{E}-03$ & 0.70 \\
\hline Dy & - & - & - & - & $5.16 \mathrm{E}-01$ & 0.59 & $6.61 \mathrm{E}-01$ & 0.99 \\
\hline $\mathrm{Er}$ & - & - & - & - & $8.99 \mathrm{E}-01$ & 0.67 & - & - \\
\hline $\mathrm{Eu}$ & - & - & - & - & $1.33 \mathrm{E}+00$ & 0.85 & $1.81 \mathrm{E}+00$ & 0.98 \\
\hline $\mathrm{Fe}$ & $1.44 \mathrm{E}-04$ & 0.36 & $8.17 \mathrm{E}-05$ & 0.34 & $4.34 \mathrm{E}-05$ & 0.36 & $3.16 \mathrm{E}-05$ & 0.96 \\
\hline $\mathrm{Ga}$ & $2.02 \mathrm{E}-07$ & 0.81 & - & - & $3.40 \mathrm{E}-02$ & 0.30 & $9.82 \mathrm{E}-02$ & 0.99 \\
\hline $\mathrm{Gd}$ & - & - & - & - & $2.52 \mathrm{E}-01$ & 0.76 & $4.45 \mathrm{E}-01$ & 0.99 \\
\hline $\mathrm{Ge}$ & - & - & - & - & $3.83 \mathrm{E}-01$ & 0.66 & - & - \\
\hline Hf & - & - & - & - & $7.50 \mathrm{E}-01$ & 0.47 & $1.30 \mathrm{E}+00$ & 0.88 \\
\hline Ho & - & - & - & - & $2.68 \mathrm{E}+00$ & 0.59 & $3.42 \mathrm{E}+00$ & 0.99 \\
\hline $\mathrm{K}$ & $2.71 \mathrm{E}-04$ & 0.78 & - & - & $9.01 \mathrm{E}-05$ & 0.52 & $1.08 \mathrm{E}-04$ & 0.93 \\
\hline $\mathrm{La}$ & $1.03 \mathrm{E}-07$ & 0.77 & - & - & $6.93 \mathrm{E}-02$ & 0.72 & $5.34 \mathrm{E}-02$ & 0.99 \\
\hline $\mathrm{Li}$ & $1.46 \mathrm{E}-07$ & 0.41 & - & - & - & - & - & - \\
\hline $\mathrm{Lu}$ & - & - & - & - & $6.41 \mathrm{E}+00$ & 0.55 & $9.92 \mathrm{E}+00$ & 0.99 \\
\hline $\mathrm{Mg}$ & $9.62 \mathrm{E}-04$ & -0.09 & - & - & $3.15 \mathrm{E}-04$ & 0.37 & $7.21 \mathrm{E}-05$ & 0.76 \\
\hline $\mathrm{Mn}$ & $6.51 \mathrm{E}-09$ & 0.22 & $2.44 \mathrm{E}-03$ & 0.14 & $2.34 \mathrm{E}-03$ & -0.22 & $1.72 \mathrm{E}-03$ & 0.92 \\
\hline Mo & $3.92 \mathrm{E}-06$ & 0.24 & - & - & $1.09 \mathrm{E}+00$ & -0.61 & $1.28 \mathrm{E}-01$ & 0.37 \\
\hline $\mathrm{Na}$ & $1.15 \mathrm{E}-03$ & 0.44 & - & - & $1.36 \mathrm{E}-04$ & 0.00 & $5.41 \mathrm{E}-05$ & 0.32 \\
\hline $\mathrm{Nb}$ & $3.60 \mathrm{E}-07$ & 0.73 & - & - & $1.91 \mathrm{E}-01$ & 0.32 & $1.88 \mathrm{E}+00$ & 0.59 \\
\hline $\mathrm{Nd}$ & - & - & - & - & $7.43 \mathrm{E}-02$ & 0.94 & $7.56 \mathrm{E}-02$ & 1.00 \\
\hline $\mathrm{Ni}$ & $2.39 \mathrm{E}-07$ & -0.15 & $1.58 \mathrm{E}-02$ & 0.20 & $3.03 \mathrm{E}-02$ & -0.07 & $9.14 \mathrm{E}-03$ & 0.94 \\
\hline $\mathrm{Pb}$ & $1.15 \mathrm{E}-07$ & 0.11 & - & - & $1.29 \mathrm{E}-01$ & -0.13 & $9.06 \mathrm{E}-03$ & 0.90 \\
\hline $\mathrm{Pd}$ & - & - & - & - & $3.18 \mathrm{E}+00$ & 0.83 & - & - \\
\hline $\operatorname{Pr}$ & - & - & - & - & $2.93 \mathrm{E}-01$ & 0.94 & $2.77 \mathrm{E}-01$ & 0.99 \\
\hline $\mathrm{Rb}$ & $5.86 \mathrm{E}-08$ & 0.88 & - & - & $2.54 \mathrm{E}-02$ & 0.52 & $3.13 \mathrm{E}-02$ & 0.98 \\
\hline $\mathrm{Sb}$ & - & - & - & - & $1.79 \mathrm{E}+00$ & -0.11 & $2.49 \mathrm{E}-01$ & -0.49 \\
\hline $\mathrm{Sc}$ & $4.40 \mathrm{E}-07$ & 0.29 & - & - & - & - & - & - \\
\hline $\mathrm{Se}$ & - & - & - & - & $4.56 \mathrm{E}-01$ & -0.41 & - & - \\
\hline $\mathrm{Sm}$ & - & - & - & - & $3.93 \mathrm{E}-01$ & 0.76 & $4.27 \mathrm{E}-01$ & 0.99 \\
\hline $\mathrm{Sn}$ & $1.82 \mathrm{E}-06$ & 0.69 & - & - & $1.50 \mathrm{E}-02$ & -0.18 & $5.73 \mathrm{E}-02$ & -0.19 \\
\hline $\mathrm{Sr}$ & $2.37 \mathrm{E}-08$ & 0.37 & - & - & $6.43 \mathrm{E}-03$ & -0.14 & $5.18 \mathrm{E}-03$ & 0.83 \\
\hline $\mathrm{Ta}$ & - & - & - & - & $1.88 \mathrm{E}+00$ & 0.89 & - & - \\
\hline $\mathrm{Tb}$ & - & - & - & - & $2.97 \mathrm{E}+00$ & 0.55 & $2.98 \mathrm{E}+00$ & 0.98 \\
\hline Th & $3.54 \mathrm{E}-07$ & 0.83 & - & - & $2.13 \mathrm{E}-01$ & 0.78 & $1.57 \mathrm{E}-01$ & 0.99 \\
\hline $\mathrm{Ti}$ & $1.28 \mathrm{E}-03$ & 0.37 & - & - & $4.09 \mathrm{E}-04$ & 0.41 & $1.17 \mathrm{E}-03$ & 0.92 \\
\hline $\mathrm{Tl}$ & - & - & - & - & $3.33 \mathrm{E}+00$ & 0.89 & $3.58 \mathrm{E}+00$ & 0.98 \\
\hline $\mathrm{Tm}$ & - & - & - & - & $6.70 \mathrm{E}+00$ & 0.41 & $9.96 \mathrm{E}+00$ & 0.99 \\
\hline $\mathrm{U}$ & $1.21 \mathrm{E}-06$ & 0.72 & - & - & 7.33E-01 & 0.81 & $6.86 \mathrm{E}-01$ & 0.93 \\
\hline $\mathrm{V}$ & $5.57 \mathrm{E}-08$ & 0.30 & $1.48 \mathrm{E}-02$ & 0.39 & $1.80 \mathrm{E}-02$ & 0.57 & $1.41 \mathrm{E}-02$ & 0.95 \\
\hline $\mathrm{W}$ & $4.18 \mathrm{E}-06$ & 0.75 & - & - & $1.36 \mathrm{E}+00$ & 0.46 & - & - \\
\hline $\mathrm{Y}$ & $2.00 \mathrm{E}-07$ & 0.75 & - & - & $1.04 \mathrm{E}-01$ & 0.44 & $1.18 \mathrm{E}-01$ & 0.97 \\
\hline $\mathrm{Yb}$ & - & - & - & - & $1.00 \mathrm{E}+00$ & 0.44 & $1.45 \mathrm{E}+00$ & 0.99 \\
\hline $\mathrm{Zn}$ & $4.65 \mathrm{E}-08$ & 0.32 & $9.86 \mathrm{E}-03$ & -0.20 & $1.88 \mathrm{E}-02$ & 0.08 & $2.32 \mathrm{E}-03$ & 0.48 \\
\hline $\mathrm{Zr}$ & - & - & - & - & $2.28 \mathrm{E}-02$ & 0.59 & $3.84 \mathrm{E}-02$ & 0.82 \\
\hline
\end{tabular}

Notes: (a) Smith et al. (2005), (b) Mullins and Kamerzell (2007), (c) This study (sampling during 2009), (d) This study (sampling during 2008) 
Table 3: Statistical data for atmospheric beryllium $\left(\mathrm{pg} / \mathrm{m}^{3}\right)$ at LLNL S200 and $\mathbf{S 3 0 0}$

\begin{tabular}{l|rr} 
& S200 & S300 \\
\hline Years Sampled & $1974-2010$ & $1981-2010$ \\
$\mathrm{~N}$ & 2913 & 2375 \\
Range & $0.1-540$ & $0.3-430$ \\
Mean & 25.9 & 24.6 \\
Standard deviation & 42.8 & 42.8 \\
Median & 12.6 & 11.0
\end{tabular}

Table 4. Ratios of 10 selected comparative markers for Be:M in facility carpet samples

\begin{tabular}{|c|c|c|c|c|c|c|c|c|c|c|c|}
\hline & \multicolumn{9}{|c|}{ Facility ID } \\
\hline & & & $\mathbf{A}$ & B & C & D & $\mathbf{E}$ & $\mathbf{F}$ & G & H-1 & H-2 \\
\hline \multicolumn{3}{|c|}{ Known Be activity $^{\mathrm{a}}$ / equipment ${ }^{\mathrm{b}}$} & No & No & No & $\mathrm{Yes}^{\mathrm{a}}$ & $\mathrm{Yes}^{\mathrm{a}}$ & $\mathrm{Yes}^{\mathrm{a}}$ & No & Yes $^{\mathrm{b}}$ & Yes $^{\mathrm{b}}$ \\
\hline Be:M Ratio & $\begin{array}{r}\text { LLNL } \\
\text { Soil }\end{array}$ & $\begin{array}{r}\text { LLNL } \\
\text { Air }\end{array}$ & & & & & & & & & \\
\hline $\operatorname{Al}\left(10^{-5}\right)$ & 2.04 & 3.76 & 2.91 & $\underline{2.31}$ & 16.0 & 187 & 17.4 & 78.9 & 1.55 & 1.86 & $\underline{6.82}$ \\
\hline Cs & 0.566 & 0.365 & 0.481 & 0.118 & 0.272 & $\underline{0.707}$ & 0.333 & $\underline{4.19}$ & $\underline{1.13}$ & 0.227 & $\underline{0.710}$ \\
\hline $\mathrm{Eu}$ & 1.33 & 1.81 & 1.09 & $\underline{1.38}$ & $\underline{8.00}$ & $\underline{37.6}$ & $\underline{8.29}$ & $\underline{17.0}$ & $\underline{2.67}$ & 0.659 & $\underline{2.35}$ \\
\hline Gd & 0.252 & 0.445 & 0.218 & 0.206 & $\underline{1.50}$ & $\underline{11.0}$ & $\underline{1.81}$ & $\underline{3.75}$ & 0.246 & 0.153 & $\underline{0.414}$ \\
\hline $\operatorname{La}\left(10^{-2}\right)$ & 6.93 & 5.34 & 3.74 & 3.60 & $\underline{16.0}$ & $\underline{314}$ & $\underline{17.2}$ & $\underline{106}$ & 5.26 & 3.15 & $\underline{7.64}$ \\
\hline $\mathrm{Nd}\left(10^{-2}\right)$ & 7.43 & 7.56 & 4.51 & 3.92 & $\underline{31.8}$ & $\underline{445}$ & $\underline{34.0}$ & 49.2 & 10.4 & 3.77 & $\underline{10.3}$ \\
\hline $\operatorname{Pr}$ & 0.293 & 0.277 & 0.174 & 0.156 & $\underline{1.11}$ & $\underline{17.9}$ & $\underline{1.18}$ & $\underline{2.03}$ & $\underline{0.449}$ & 0.143 & $\underline{0.361}$ \\
\hline $\mathrm{Sm}$ & 0.393 & 0.427 & 0.266 & 0.125 & $\underline{1.70}$ & $\underline{18.3}$ & $\underline{1.65}$ & $\underline{8.04}$ & $\underline{0.615}$ & 0.207 & $\underline{0.690}$ \\
\hline Th & 0.213 & 0.157 & 0.169 & 0.128 & $\underline{1.51}$ & $\underline{23.0}$ & $\underline{1.63}$ & $\underline{3.32}$ & $\underline{0.404}$ & 0.139 & $\underline{0.443}$ \\
\hline $\mathrm{Tl}$ & 3.33 & 3.58 & $\underline{5.00}$ & $\underline{6.56}$ & $\underline{11.7}$ & $\underline{589}$ & $\underline{13.6}$ & $\underline{29.0}$ & $\underline{9.64}$ & 2.90 & $\underline{10.0}$ \\
\hline & Number $>$ L & NL Soil & 2 & 3 & 9 & 10 & 9 & 10 & 7 & 0 & 10 \\
\hline & Number $>$ I & NL Air & 3 & 1 & 9 & 10 & 9 & 10 & 7 & 0 & 9 \\
\hline
\end{tabular}

